\title{
Transatlantic Tales and Democratic Dreams: Archbishop Gaetano Bedini, Alessandro Gavazzi, and the Struggle to Define Republican Liberty in a Revolutionary Age, 1848-1854
}

Andrew Mach

West Virginia University

Follow this and additional works at: https://researchrepository.wvu.edu/etd

\author{
Recommended Citation \\ Mach, Andrew, "Transatlantic Tales and Democratic Dreams: Archbishop Gaetano Bedini, Alessandro \\ Gavazzi, and the Struggle to Define Republican Liberty in a Revolutionary Age, 1848-1854" (2014). \\ Graduate Theses, Dissertations, and Problem Reports. 107. \\ https://researchrepository.wvu.edu/etd/107
}

This Thesis is protected by copyright and/or related rights. It has been brought to you by the The Research Repository @ WVU with permission from the rights-holder(s). You are free to use this Thesis in any way that is permitted by the copyright and related rights legislation that applies to your use. For other uses you must obtain permission from the rights-holder(s) directly, unless additional rights are indicated by a Creative Commons license in the record and/ or on the work itself. This Thesis has been accepted for inclusion in WVU Graduate Theses, Dissertations, and Problem Reports collection by an authorized administrator of The Research Repository @ WVU. For more information, please contact researchrepository@mail.wvu.edu. 
Transatlantic Tales and Democratic Dreams:

Archbishop Gaetano Bedini, Alessandro Gavazzi, and the Struggle to Define Republican Liberty in a Revolutionary Age, 1848-1854

\author{
Andrew Mach \\ Thesis submitted to the \\ Eberly College of Arts and Sciences \\ at West Virginia University \\ in partial fulfillment of the requirements \\ for the degree of \\ Master of Arts \\ in \\ History
}

\begin{abstract}
Brian Luskey, Ph.D., Chair
Aaron Sheehan-Dean, Ph.D.

Ken Fones-Wolf, Ph.D.

Department of History
\end{abstract}

Morgantown, West Virginia
2014

Keywords: Gaetano Bedini; Alessandro Gavazzi; transatlantic anti-Catholicism; political culture; Cincinnati; Catholic Church; natural rights liberalism; ultramontanism; nativism; 1848 exiles; civic rioting

Copyright 2014 Andrew Mach 


\section{ABSTRACT \\ Transatlantic Tales and Democratic Dreams: Archbishop Gaetano Bedini, Alessandro Gavazzi, and the Struggle to Define Republican Liberty in a Revolutionary Age, 1848-1854}

\section{Andrew Mach}

Catholic Archbishop Gaetano Bedini's 1853-1854 visit to the United States catalyzed a series of disturbances and debates over the limits of responsive government, free speech, and religious liberty. The Papal Nuncio's supporters and critics both drew on transatlantic tales and republican visions, casting the "Bedini Affair" as a subversive attack on ultramontane Catholic theology, embarrassing national spectacle, legitimate protest of an 1848 counterrevolutionary, or Protestant defense of exceptionalist ideals against papal "aggression" and conspiracy. The Know Nothing Party's emergence on the national political scene months after the Nuncio's visit obscured these competing narratives and ensured that nativist retellings became the authoritative accounts of the Bedini Affair. This thesis returns the Archbishop's tour to its original social, political, and religious contexts, revealing the importance of immigrant political activism, the impact of cultural narratives on American life and politics, and the uneasy relationship between constitutional theory and antebellum republican practice.

The career of Bedini's harshest critic, Italian apostate priest Alessandro Gavazzi, illustrated the international dimensions of anti-Catholic thought and rhetoric. A well-known revolutionary army chaplain and orator, the Bologna native renounced his vows after concluding that the Vatican would never support Italian democracy. After fleeing his homeland with the help of an American diplomat, Gavazzi launched a controversial lecture tour through Britain, Canada, and the United States. Mixing standard anti-Catholic stereotypes with allusions to recent Church "aggressions" and fierce denouncements of Pope Pius IX and later Bedini, the so-called "Butcher of Bologna," the former Barnabite friar portrayed his old faith as a spiritually superstitious and politically repressive medieval relic. European exiles and American nativists adapted these tales to suit their own political purposes, transforming Bedini from an unassuming visitor into the embodiment of Catholic autocracy and depravity.

These sensationalized stories sparked protests in urban immigrant centers across the United States, showcasing differing partisan, religious, and ethnic interpretations of law and order. Catholic and Democratic elites in cities such as Cincinnati condemned the Bedini "riots," while nativists, former Whigs, and exiles cast the "protests" as evidence of robust democracy. These disturbances showed that antebellum political debates could transcend sectarian and sectional agendas to contest the very meanings of civil liberty and constitutional government. 


\section{Table of Contents}

I. Introduction: Cultural Fictions and the Transnational Fight for Freedom, Pages 113

II. Atlantic Riots and Catholic "Aggression": Competing Views of Republicanism and Church-State Relations, Pages 14-39

III. Free Speech or Violent Insurrection? Political and Rhetorical Reactions to the Cincinnati "Bedini Affair," Pages 40-69

IV. Conclusion: The Many Affairs of Gaetano Bedini, Pages 70-91

V. Bibliography, Pages 92-96 


\section{Introduction}

\section{Cultural Fictions and the Transnational Fight for Freedom}

On August 22, 1853, religious devotion and revolutionary republicanism collided on the morning train to Montreal when Catholic Archbishop Gaetano Bedini and his fiercest foe, Alessandro Gavazzi, entered the same railcar and seated themselves within feet of one another. The appearance of these middle-aged Italians attracted little attention from casual American riders, despite the sharp ideological and theological divides separating the orthodox papal ambassador, or nuncio, from his republican opponent. Gavazzi, the Bolognese ex-priest whose long, jet-black hair and memorable stage presence were iconic on the international anti-Catholic lecture circuit, told applauding crowds of Anglo-American Protestants and European exiles that Pope Pius IX was to blame for Italy's continued foreign subjugation. Recently, he had expanded his repertoire to attack Bedini, the "Butcher of Bologna" responsible for the executions of innocent revolutionaries in 1849. Bedini, the quiet prelate whose elegant manners reflected his training as a Vatican diplomat, believed that answering such outrageous charges fell beneath his dignity. ${ }^{1}$ In the face of Gavazzi's continued rabblerousing, Bedini remained silent. Yet the former could not be quieted: already that summer he had ignited bloody riots in Canada, and soon Bloody Bedini tales would spark urban dissent across the Midwest and Mid-Atlantic. But here at the Saratoga Springs train station in upstate New York, the two adversaries remained

\footnotetext{
${ }^{1}$ James Connelly, The Visit of Archbishop Gaetano Bedini to the United States of America: June 1853February 1854 (Rome: Pontifical Gregorian University, 1960), 33-34; Dan Horner, “'Shame upon you as men!': Contesting Authority in the Aftermath of Montreal's Gavazzi Riot," Social History 44 (2011): 36; Thomas O’Connor, Fitzpatrick's Boston, 1846-1866: John Bernard Fitzpatrick, Third Bishop of Boston (Boston: Northeastern University Press, 1984), 141; Archbishop Gaetano Bedini, letter to Archbishop John Hughes, February 3, 1854, Archbishop John Hughes Papers, American Catholic History Research Center and University Archives, Catholic University of America (Washington, DC).
} 
tight-lipped, exchanging neither word nor gesture before Gavazzi stepped off the train at Lake George and Bedini continued north toward Montreal. ${ }^{2}$

As the Archbishop tarried in North America, however, a crisis atmosphere gripped the United States as politicians, religious leaders, immigrants, and nativists responded to Gavazzi's fearful tales. Italian and German exiles from the failed revolutions of 1848 took strong stands against Bedini, who they believed personified Pius IX's reactionary policies. Ethnic leaders and newspaper editors, especially in Cincinnati and New York, described Bedini's alleged past and organized raucous rallies and effigy burnings. Distrustful of the exiles' socialist tendencies and fearful that their public protests might breach the civic peace, authorities responded by directing law enforcement officials to rein in the demonstrators. Such heavy-handed tactics backfired on Christmas Day, 1853, when unprovoked police attacks on German-American protestors in Cincinnati unleashed the pent-up frustrations of residents. Tired of political corruption, stressed by continual ethnic, religious, and racial strife, and disgusted with police crackdowns on free speech, native-born voters rallied to the immigrants' cause. Sparked by international events and fanned by local political factors and concerns, anti-Bedinism spread like wildfire across the United States. In Washington, senators debated the meanings of the Archbishop's visit, while newspapers that had barely noticed the unremarkable diplomat now followed his travels with ceaseless interest. ${ }^{3}$ Nativists joined exiles at protests in Boston and New York, while American Catholic bishops - many of whom were immigrants themselves - found solace in theology, arguing that anti-Bedinism was a crown of thorns placed upon their heads by Christ. In preceding months, Bedini had traveled from New York to Milwaukee before sailing the Great Lakes, riding

\footnotetext{
${ }^{2}$ Connelly, Visit of Archbishop Gaetano Bedini, 33-34, 91-141; Horner, "Contesting Authority," 29-32.

${ }^{3}$ Connelly, Visit of Archbishop Gaetano Bedini, 101-102, 122-125; Bruce Levine, The Spirit of 1848: German Immigrants, Labor Conflict, and the Coming of the Civil War (Urbana: University of Illinois Press, 1992), 188-191; Mary Alice Mairose, "Nativism on the Ohio" (M.A. thesis, The Ohio State University, 1993), 92-93; Weekly Herald (New York), December 31, 1853.
} 
the rails to Canada, and chastising heterodox parish trustees in Buffalo, all the while bestowing the Holy Father's blessing on the faithful and trying to strengthen the Vatican's relations with the New World. Yet his blessings seemed cursed: by the time Bedini passed through Wheeling and Washington on the way to his February 1854 departure from New York Harbor, mere mention of the "Butcher's" whereabouts sparked panic and upheaval. ${ }^{4}$

Scholars have traditionally linked this rash of rioting to the growing antebellum nativist movement that emerged as the politically potent Know Nothing Party just months after the Archbishop's return to Rome. Frustrated by economic stagnation and political corruption, nativeborn citizens desperately sought to scapegoat the ever-growing numbers of Irish and German immigrants and reestablish their political primacy. ${ }^{5}$ At the same time, scholars have argued, vociferous street preachers and popular fictional accounts of convent life helped fan the flames of anti-Vatican sentiment. New York Archbishop John Hughes's outspoken support for publiclyfunded parochial schools and President Franklin Pierce's appointment of the Catholic James Campbell as U.S. Postmaster General only intensified this hatred, as many Protestants began to fear a papal takeover of the United States. And then, as if to confirm these fears, an unknown foreign archbishop with a suspicious past appeared without warning. Anxious for their country's future and infuriated by continued Catholic intransigence, Americans responded quickly and decisively. On the streets, in congressional chambers, and in newspapers, they launched a fullscale offensive against Bedini, using the same political tactics and organization that would soon sweep nativist leaders to power on Know Nothing electoral tickets.

\footnotetext{
${ }^{4}$ Connelly, Visit of Archbishop Gaetano Bedini, 17-31; Weekly Herald, June 24, 1854; Archbishop Gaetano Bedini, letter to Archbishop John Purcell, December 30, 1853, Archdiocesan Records, Electronic Archival Calendar, University of Notre Dame Archives (Notre Dame, Ind.).

${ }^{5}$ Tyler Anbinder, Nativism and Slavery: The Northern Know Nothings and the Politics of the 1850s (New York: Oxford University Press, 1992); Ray Allen Billington, The Protestant Crusade 1800-1860: A Study of the Origins of American Nativism (New York: The Macmillan Company, 1938); David Endres, "Know Nothings, Nationhood, and the Nuncio: Reassessing the Visit of Archbishop Bedini," U.S. Catholic Historian 21 (2003): 1-16.
} 
Catholic historians have adopted similar analytical frameworks even as they have worked to redeem the Archbishop's reputation. Like their lay peers, Church historians have tended to place Bedini's visit within the antebellum period's larger anti-immigrant and anti-Catholic context. Yet unlike secular scholars, who grounded their analyses in newspaper accounts and nativist writings, religious writers have leaned heavily on the correspondence of high-ranking Church leaders such as Archbishops John Hughes and John Purcell. The sources may be different, but in the end the results almost match, as both scholarly camps portray Bedini's opponents as homogeneous mobs of anti-Catholic agitators. ${ }^{6}$ In secular accounts, nativism propels the rioters onward; in Church histories, atheism and evangelical distrust of the Church fuels the disturbances. Heavy on Protestantism and the Pope, these accounts rarely analyze the actual protestors: neither camp has wrestled with the presence of both nativists and immigrants at rallies or discussed the use of foreign rhetoric to support domestic rioting. ${ }^{7}$ Similarly, few lay scholars have investigated Gavazzi's claims about the Archbishop's conduct in Bologna. Rather than assessing the validity of these stories, they have focused on the tales' rhetorical power. In stark contrast, Catholic works have vigorously defended the prelate's innocence and portrayed anti-Bedinism as a coordinated yet ultimately unsuccessful assault on Catholicism. In secular histories, the Archbishop's visit undermined the American Church by stirring up ethnic tensions and nativist politics. In self-affirming Catholic histories, public resistance to Bedini increased the laity's resolve and vindicated Church teachings.

My research has uncovered key weaknesses in both of these narratives. In this thesis, I argue that Bedini's visit reveals the international dimensions of anti-Catholicism and provides

\footnotetext{
${ }^{6}$ Peter Guilday, "Gaetano Bedini: An Episode in the Life of Archbishop John Hughes," Historical Records and Studies 23 (1933): 87-170; Connelly, Visit of Archbishop Gaetano Bedini.

${ }^{7}$ Most scholars simply clump immigrants and anti-immigrant nativists together without comment. See Guilday, "Gaetano Bedini," 118: Bedini's "presence in the country was not effecting an ameliorating change in the minds of the Know Nothings and their adherents, the Italian and German radicals."
} 
new cultural and political avenues for exploring domestic democratic debates. Indeed, scholars often passed over the very questions and conundrums that made Bedini and Alessandro Gavazzi such unique and important transnational characters. Analyzing these travelers' stories produces new insights in political, social, cultural, intellectual, and religious history. Unlike in most previous sectarian demonstrations, for instance, anti-Bedini protestors explicitly denied that they were attacking Catholic spirituality; instead, worldly affairs motivated their actions and messages. ${ }^{8}$ Behind sensationalist Bolognese tales and popular protests lay divided societies grappling with competing conceptions of democracy and civil authority. German marchers believed Gavazzi's republican sagas and marched to protest the supposed executions of Italians, nativists corroborated the tales of a foreign ex-priest, and American demonstrators cited the values and heroes of the 1848 European revolutions. In this thesis, I dissect the various ethnic and political groups involved in these events and challenge previous studies of antebellum rioting. I also explore how residents across the North Atlantic crafted competing cultural narratives to support their preferred views of citizenship, democracy, and the relationship between church and state. Native-born citizens espoused American exceptionalism even as they internalized international themes, producing contradictory answers to questions about which ethnic groups should be welcomed as voters, what qualities distinguished respectable citizens, and what types of free speech should be permitted in society.

This work builds on studies of antebellum democratic culture that showed how electoral cycles contributed to the United States' turbulent, and often violent, political climate. In Civic Wars, Mary Ryan revealed how partisanship catalyzed urban conflict. During the first decades of the nineteenth century, she argued, Jeffersonian and Jacksonian politics supported the proliferation of public meetings, rallies, and symbolic riots that expanded the political sphere and

\footnotetext{
${ }^{8}$ Cincinnati Daily Enquirer, December 29, 1853.
} 
developed informal links between "the people" and their government. By the 1850 s, however, political parties emphasized difference rather than diversity while peaceful assemblies of competing groups morphed into harsh, angry bands separated by politics, ethnicity, and class. ${ }^{9}$

Local forces lay at the heart of Ryan's analysis, as she suggested that rioting was largely a response to city politics and growing despair over political corruption. Other scholars have linked the growth of violent street politics to a breakdown in traditional deference or the corrupting and pervasive influence of slavery. ${ }^{10}$ In contrast, Daniel Cohen and Ian Radforth looked beyond the ballot box to study the rhetoric and symbolism employed by protestors. While antebellum riots and effigy burnings seemed spontaneous, demonstrators in Boston, Montreal, and elsewhere often drew on English republican traditions and common cultural scripts to symbolically cleanse their communities and bolster public liberty. ${ }^{11}$

Renewed focus on British and Canadian civil society has coincided with increased scholarly interest in transatlantic political culture, although religious history still seems bound by national borders. Traditionally, the nineteenth century has been portrayed as an insular period. Scholars have emphasized domestic struggles over states' rights and slavery even as authors such as Bernard Bailyn and Thomas Bender pioneered landmark transnational studies of the American Revolution and early twentieth century. Yet new literature has begun to explore the ideological

\footnotetext{
${ }^{9}$ Mary Ryan, Civic Wars: Democracy and Public Life in the American City during the Nineteenth Century (Berkeley: University of California Press, 1997), 115-139.

${ }^{10}$ Kimberly Smith, The Dominion of Voice: Riot, Reason, and Romance in Antebellum Politics (Lawrence: University of Kansas Press, 1999), 25-52; Glenn Altschuler and Stuart Blumin, Rude Republic: Americans and Their Politics in the Nineteenth Century (Princeton: Princeton University Press, 2001), 11, 47, 151; David Grimsted, American Mobbing, 1828-1861: Toward Civil War (New York: Oxford University Press, 1998), viii-ix, $229-230$.

${ }^{11}$ Daniel Cohen, "Passing the Torch: Boston Firemen, 'Tea Party' Patriots, and the Burning of the Charlestown Convent," Journal of the Early Republic 24 (2004): 527-586; Ian Radforth, "Political Demonstrations and Spectacles during the Rebellion Losses Controversy in Upper Canada," Canadian Historical Review 92 (2011): 1-41.
} 
and personal links between revolutionary Europe and democratic America. ${ }^{12}$ American, German, and Italian scholars have all tracked the ways in which 1848 fighters' radical political beliefs and bloody experiences later affected their actions in exile, while Timothy Roberts' Distant Revolutions illustrates how reports of European turmoil contributed to the United States' growing sense of national destiny and exceptionalism. ${ }^{13}$ Despite Catholicism's obvious international links to the Vatican, however, scholars of both Church history and anti-Catholicism have mainly eschewed transnational studies. Peter D'Agostino's study of Rome in the American imagination and Timothy Verhoeven's analysis of religion and gender in the United States and France pointed the way forward, but only a handful of authors have followed. Most of these resulting works are bilateral analyses that emphasize the transfer of ideas rather than the movement of persons. Concerns about the Vatican's temporal power are similarly given short shrift in these studies, overshadowed by gendered literary analyses of Catholicism's opposition to the Protestant cults of female virtue and domesticity. ${ }^{14}$

\footnotetext{
${ }^{12}$ W. Caleb McDaniel, The Problem of Democracy in the Age of Slavery: Garrisonian Abolitionists and Transatlantic Reform (Baton Rouge: Louisiana State University Press, 2013); Edward Rugemer, The Problem of Emancipation: The Caribbean Roots of the American Civil War (Baton Rouge: Louisiana State University Press, 2009).

${ }^{13}$ Levine, Spirit of 1848; Mischa Honeck, We Are the Revolutionists: German-Speaking Immigrants \& American Abolitionists after 1848 (Athens: University of Georgia Press, 2011); Maurizio Isabella, Risorgimento in Exile: Italian Émigrés and the Liberal International in the Post-Napoleonic Era (New York: Oxford University Press, 2009); Paola Gemme, Domesticating Foreign Struggles: The Italian Risorgimento and Antebellum American Identity (Athens: University of Georgia Press, 2005); Timothy Roberts, Distant Revolutions: 1848 and the Challenge to American Exceptionalism (Charlottesville: University of Virginia Press, 2009).

${ }^{14}$ Peter D'Agostino, Rome in America: Transnational Catholic Ideology from the Risorgimento to Fascism (Chapel Hill: University of North Carolina Press, 2004); Timothy Verhoeven, Transatlantic Anti-Catholicism: France and the United States in the Nineteenth Century (Basingstoke, England: Palgrave Macmillan, 2010); Susan Griffin, Anti-Catholicism and Nineteenth-Century Fiction (Cambridge: Cambridge University Press, 2004); Elizabeth Fenton, Religious Liberties: Anti-Catholicism and Liberal Democracy in Nineteenth-Century U.S. Literature and Culture (New York: Oxford University Press, 2011); John Wolffe, "North Atlantic Anti-Catholicism in the Nineteenth Century: A Comparative Overview," in European Anti-Catholicism in a Comparative and Transnational Perspective, eds. Yvonne Werner and Jonas Harvard (Amsterdam: Rodopi, 2013), 25-41; John Wolffe, "A Transatlantic Perspective: Protestantism and National Identities in mid-Nineteenth-Century Britain and the United States," in Protestantism and National Identity: Britain and Ireland 1660-1850, eds. Tony Claydon and Ian McBride (Cambridge: Cambridge University Press, 1998), 291-309; Timothy Verhoeven, "Neither Male nor Female: Androgyny and International Anti-Catholicism," Australasian Journal of American Studies 24 (2005): 5-19; Elizabeth Fenton, "Birth of a Protestant Nation: Catholic Canadians, Religious Pluralism, and National Unity in the
} 
My thesis contributes to this nascent historiography by analyzing transnational debates over Catholic power and democratic dissent. I show how revolutionary ideologies and exiles, along with popular fears over Pius IX's restoration, contributed to an Atlantic-wide questioning of representative government. In Britain, Canada, and the United States, concerned Protestants were incensed by even the slightest post-1848 "papal aggression" or "provocation," while the same democratic and egalitarian forces that sparked revolutions in Europe took on more subtle but no less serious natures in North America. This thesis analyzes cultural narratives as well as the riots they inspired, shedding light on how concerns over church and state, sectarianism, "mobocracy," and national character motivated protestors. Political concerns soon came to the fore: elites called for a stable republican order that prized hierarchy and virtue, even as activists argued that more, not less, public involvement was necessary to preserve freedom. ${ }^{15}$ By returning Bedini and Gavazzi to their proper international, cultural, and religious contexts, this thesis reveals political currents of dissent that affected civic leaders, electoral partisans, and activists across the North Atlantic.

My analysis also complements American political histories by highlighting the inherently contentious nature of antebellum democracy. While scholars such as Mary Ryan have illustrated how popular elections and hot-button issues provoked antebellum rioting, few have examined how these demonstrations challenged the foundational assumptions of constitutional government. As fallout from Bedini's visit suggests, portions of the antebellum population - especially liberal immigrant groups - sought more than just the opportunity to symbolically influence the body

Early U.S. Republic,” Early American Literature 41 (2006): 29-57; Marjule Drury, “Anti-Catholicism in Germany, Britain, and the United States: A Review and Critique of Recent Scholarship," Church History 70 (2001): 98-131; Stephen Kenny, "A Prejudice that Rarely Utters its Name: An Historiographical and Historical Reflection upon North American Anti-Catholicism," American Review of Canadian Studies 32 (2002): 639-672.

${ }^{15}$ London Examiner (England), July 20, 1850; September 14, 1850; Morning Chronicle and Commercial and Shipping (Quebec City), June 11, 1853; National Era (Washington, DC), January 27, 1854; Cayuga Chief (Auburn, NY), January 31, 1854. 
politic. They desired true influence in a more responsive and direct democracy in which the people, not bureaucrats and career politicians, held power. Many Democratic politicians and city elites disagreed, arguing that the rule of law protected American civilization from demagoguery and ultimate collapse. ${ }^{16}$ Because these concerns remained after election cycles concluded, scholarly depictions of party operatives whipping up partisan riots portray only a partial view of rioting and antebellum political culture. Debates over sectionalism, slavery, economics, and religion certainly inflamed numerous crowds, but the fundamental battle to define and control America's democratic soul often lay at the heart of this rhetoric.

Analyzing these democratic debates and cultural narratives requires placing Gavazzi’s and Bedini's travels within the larger Atlantic frameworks of anti-Catholicism and radical activism. Wherever midcentury Anglo-American Protestants looked, Catholicism posed a clear and present threat to republican institutions. Because Church gains were equated to autocratic victories after Pope Pius IX's alleged "betrayal" of Italian freedom, many Protestants and radical agnostics - despite their serious sectarian and political differences - agreed that the Church stood poised to crush Continental republicanism and plunge modern Anglo-America back into medieval monarchy. Primed to view any Catholic action as an intolerant and tyrannical attack on constitutional freedoms, these citizens saw events such as Britain's "Papal Aggression," Canada's Gavazzi Riots, Bedini's ride on the U.S.S. Michigan, and the Nuncio's determined opposition to parish trustees as "proof" of the Church's sinister nature and despotic tendencies. Gavazzi's dramatic speeches and exaggerations further exemplified the exiles' efforts to prove Europe's fitness for freedom and gain popular acceptance of liberal ideology. This thesis analyzes popular rhetoric, symbols, and actions, drawing on shared cultural ideals and the

\footnotetext{
${ }^{16}$ Smith, The Dominion of Voice, 15-54.
} 
controversial visits of Gavazzi and Bedini to explore the papal conspiracy theories and temporal conflicts that distinguished midcentury Atlantic democracy.

In Cincinnati, these sensationalist tales and liberal beliefs collided with domestic concerns and native-born notions of law and order, fueling the conflict misleadingly remembered as the "Bedini Affair." Swayed by Gavazzi’s republican pleas, German-American activists insisted on punishing Bedini for supposedly executing Italian patriots and opposing democratic freedoms. In 1848, national revolutionary campaigns had barely acknowledged, let alone cooperated with, one another; now, half a decade later and thousands of miles away from European battlefields and barricades, exiles universalized, and later Americanized, their national manifestos into coherent, all-encompassing liberal ideologies. ${ }^{17}$ As exiles grew politically accepted and increasingly emboldened, Cincinnati Archbishop John Purcell hunkered down for an extended siege against lawless radicals and atheist provocateurs, trusting that his sufferings would strengthen faith and win converts. ${ }^{18}$ At first, native-born Protestants likewise decried the German Freemen's violent agnosticism, describing the foreigners' Christmas protest against Bedini as a violent attack on civic sensibilities and hospitality. Yet later reports of police brutality turned public opinion in favor of the protestors. ${ }^{19}$ Unnerved by the Germans" "riot," Cincinnatians were nonetheless infuriated by the police's infringement on civil liberties, igniting a lengthy series of partisan arguments, newspaper editorials, court testimonies, and effigy burnings that sought to define the proper limits of free speech. Democratic Mayor David Snelbaker called for republican restraint, but supporters of natural rights liberalism painted his

\footnotetext{
${ }^{17}$ Axel Körner, ed., 1848 - A European Revolution? International Ideas and National Memories of 1848 (New York: St. Martin’s Press, 2000), 5.

${ }^{18}$ Archbishop John Purcell, letter to Cardinal James Fransoni, January 12, 1854, Archdiocesan Records, Electronic Archival Calendar, University of Notre Dame Archives (Notre Dame, Ind.); Archbishop Anthony Blanc, letter to Archbishop John Purcell, January 12, 1854, Archdiocesan Records, Electronic Archival Calendar, University of Notre Dame Archives (Notre Dame, Ind.).

${ }^{19}$ Mairose, "Nativism on the Ohio," 92-93; Daily Cincinnati Gazette, January 6, 1854.
} 
preemptive police actions as autocratic aggressions. These debates highlighted the loose political coalitions formed after the Whig Party's national demise, demonstrated immigrants' ability to influence antebellum American politics, and underscored the partisan, ethnic, and religious divisions that impeded popular efforts to define law and order. The "Bedini Affair" had as much to do with the city's continuing conflicts over religious pluralism, citizenship, civic activism, free speech, and republican government as it did with the Nuncio.

News of the Cincinnati disturbances galvanized national politicians, newspaper editors, exiles, nativists, and bishops, prompting various explanations for the violence and vitriol that accompanied Bedini's American tour. Using letters, editorials, public bulletins, newspaper articles, and congressional debates, I piece together these contrasting narratives and show how past historians emphasized nativist accounts at the expense of Catholic, Democratic, immigrant, and sectional renditions. While Bedini and his fellow prelates mainly discussed the spiritual dimensions of the protests, Michigan Democratic Senator Lewis Cass attacked the Nuncio's opponents to protect his son, the American chargé d'affaires in Rome, and renewed his vision for a reasoning and respectable republic. Meanwhile, nativists successfully transformed the exiles' radical stand against Bedini, the 1848 counterrevolutionary, into a Protestant defense of virtue and domestic liberty. Gavazzi and other exiles created fictive accounts of the Archbishop's past to mobilize support for cosmopolitan republican values and secular government; in contrast, the nativists' anti-Bedini accounts reflected the same sensationalist descriptions and themes that distinguished earlier nunnery tales and sectarian polemics. By early January 1854, the Nuncio's visit had become an ideological debate, diplomatic scandal, religious trial, and interethnic conflict. These opposing narratives of the "Bedini Affair" illustrated the contradictions and key debates of the antebellum era, revealing the competing worldviews and differing values espoused 
by various constituencies. Bishops, leaders, and activists all sought to refashion popular memories of 1848 and use Bedini-inspired rhetoric - ranging from speeches and riot accounts to dramatic "retellings" of either atheistic immorality or Catholic depravity - to garner support for their own views of republican virtue, democratic dissent, and authentic human freedom.

This history of anti-Catholicism and democracy presents Gavazzi's and Bedini's contentious travels as emblematic of the transnational forces and contested ideologies that shaped North Atlantic political culture in the years following the 1848 revolutions. Continental exiles brought secularist and oftentimes socialist ideologies to their new homes in England and North America, where these radical beliefs were widely scorned by political elites and religious leaders. Catholic residents, whether immigrant or native-born, were similarly eyed with suspicion by Protestants who denounced the papacy's superstitions and supposed desire for temporal power. For Gavazzi and the German Freemen, Bedini's tour presented the opportunity to show native-born residents how revolutionary European values resonated with constitutional principles. Exiles denounced the Church's conspiratorial nature and upheld the values of human freedom and autonomy, even as Catholics argued that this "false" freedom crushed individual souls and encouraged civic discord. Bishops instead emphasized Bedini's link to the Church's collective wisdom and moral clarity, as represented by Pope Pius IX. Meanwhile, exile and nativist agendas briefly intersected as both groups crafted elaborate tales of Bolognese treachery and deceit to underscore the dangers of unfettered Catholicism. The North American travels of Gavazzi and Bedini also catalyzed domestic conflicts, injecting international themes and violence into continuing local debates over the limits of responsible government. By viewing these developments through cultural lenses, I show how fictive accounts influenced AngloAmerican political culture, helping adherents conceptualize evil and garner support for preferred 
republican and religious outcomes. Nativists invented memories of Bedini's visit to strengthen Protestant ideals in the face of disturbing demographic and democratic changes, just as the German Freemen used supposed accounts of the "Butcher of Bologna" to gain acceptance for liberal democracy. In the end, what Bedini said and did mattered little compared to the hopes and fears he embodied. 


\section{Chapter One}

\section{Atlantic Riots and Catholic "Aggression": Competing Views of Republicanism and Church-State Relations}

Protestant and republican leaders on both sides of the Atlantic hailed Giovanni Maria Mastai-Ferretti's 1846 election as Pope Pius IX as the dawn of a new liberal age. For centuries, the Church's harshest critics had cited Reformation theology and Enlightenment rationality to describe the papacy as an unholy alliance of earthly power and spiritual influence. The pope and his Jesuit minions were believed to conspire against empires and topple republics, just as local priests terrorized parishioners into believing superstitious and outdated doctrines. Numerous American preachers debated whether "the Roman Catholic Religion, in any or all its principles and doctrines, [is] opposed to Civil and Religious Liberty," while polemics praised Protestantism for boosting civic morality and economic prosperity. ${ }^{20}$ Yet many Italian republicans nurtured more hopeful views of the Church, decrying the Vatican's bloated bureaucracy and autocratic rule even as they dreamed of the day when the Holy Father would unite their homeland's various states under the papal banner and rule of law. These hopes seemed dashed by Pope Gregory XVI's crackdown on modern republican thought, but were resurrected when Pius freed his predecessor's political prisoners, relaxed censorship, and endorsed constitutional reforms. Italians greeted their presumed liberator with flowers, music, and loud cheers in Rome, while thousands of Protestant and Catholic New Yorkers gathered at the Broadway Tabernacle on November 29, 1847 in support of the new pontiff's "enlightened policy and liberal measures."21

\footnotetext{
${ }^{20}$ Peter Guilday, lecture notes, folder 6, box 75, Peter Guilday Papers, American Catholic History Research Center and University Archives, Catholic University of America (Washington, DC). See also D'Agostino, Rome in America, 19-25; Billington, Protestant Crusade, 1-131.

${ }^{21}$ D'Agostino, Rome in America, 19, 20-26; Dale Light, Rome and the New Republic: Conflict and Community in Philadelphia Catholicism between the Revolution and the Civil War (Notre Dame, Ind.: University of
} 
Atlantic observers followed Pius's every move, certain that he endorsed the Church's growing rapprochement with modernity.

These hopes were dashed on April 29, 1848, when Pius publicly condemned northern Italy's growing war with Austria. From Rome, the Holy Father had watched with growing concern as Milanese rebels stubbornly resisted Habsburg troops and strengthened calls for a united nation. Piedmont troops and volunteers flooded the front lines, while nationalists sought military and moral support from Pius. The Holy Father privately sympathized with these patriotic sentiments, but remained unwilling to declare war on another Catholic nation. His subsequent pronouncement sounded the death knell of moderate Italian republicanism, as activists and political leaders concluded that the papacy would never reconcile itself with political freedom. In the wake of Pius's allocution, the same republicans who once called on the pope to serve as president of Italy now joined with anticlerical political radicals who sought to abolish the Vatican's land holdings and institute secular government. These popular demonstrations and political threats forced Pius to flee into temporary exile at Gaeta, where he awaited the results of France's and Austria’s military campaigns against Italian independence. ${ }^{22}$

Pius's apparent about-face strengthened popular anti-Catholic sentiment across North America and Europe, proving to Protestants and political exiles that the Church could not coexist with religious pluralism and republican principles. This realization led Alessandro Gavazzi, a Bolognese Barnabite friar and prominent revolutionary orator, to reject his religious vows, flee his country, and dedicate the remainder of his life to exposing the papacy's degrading effects on Italy. ${ }^{23}$ Gavazzi's midcentury lecture tour through Britain, Canada, and the United States

Notre Dame Press, 1996), 310-313; Frank Coppa, Pope Pius IX: Crusader in a Secular Age (Boston: Twayne Publishers, 1979), 43-54.

${ }^{22}$ Coppa, Pius IX, 78-111; D’Agostino, Rome in America, 23; Roberts, Distant Revolutions, 5-10.

${ }^{23}$ D'Agostino, Rome in America, 33; Light, Rome and the New Republic, 319-320. 
underscored the shared cultural traditions and demographic trends that fueled Anglo-American anti-Catholicism, even as it highlighted the importance of local ethnic and political conflicts. The apostate priest's contentious rhetoric catalyzed protests and riots against another Italian traveler, Archbishop Gaetano Bedini, whose American tour was marred by assassination plots and a series of debates in Milwaukee, Detroit, Buffalo, and Washington over the Church's relationship with liberty and democratic government. As the intertwined careers of Bedini and Gavazzi reveal, memories of past European rebellions mixed with older cultural prejudices and contemporary political concerns to fuel a transnational movement that sought to define and defend republicanism by contrasting liberal principles with Catholic intolerance and theocracy.

This transatlantic rhetoric was rooted in the nationalist fervor and civic chaos that gripped Europe during the 1848 revolutions. In February, Parisian rebels inaugurated this "springtime of the peoples" by overthrowing King Louis Philippe and ushering in a short-lived era of universal male suffrage and egalitarianism. ${ }^{24}$ Angered by the same factors that mobilized the French - crop failures, recessions, high unemployment, social and economic inequality, and autocratic rule Hungarians, Germans, and Italians soon rose up against their aristocratic rulers. Many Americans initially cheered these supposed recreations of 1776, as Hungarian "Founding Father" Louis Kossuth declared an end to absolutism on March 3 and Prussian King Frederick Wilhelm IV acceded to a series of popular liberal reforms. ${ }^{25}$ Revolutionary prospects seemed more precarious in the Italian states, however, where nationalists squared off against Austrian forces and the Vatican. Pius's allocution would prove prophetic: German republican momentum soon stalled, Kossuth fled the military frontlines for exile in England, and France descended into a civil war between republicans and socialists. Louis Napoleon soon emerged as President of France, and

\footnotetext{
${ }^{24}$ Roberts, Distant Revolutions, 6.

${ }^{25}$ Roberts, Distant Revolutions, 6-9; Levine, Spirit of 1848, 24-44; Light, Rome and the New Republic, 313.
} 
under his orders troops suppressed the Roman Republic and returned Pius IX to political power. By 1851, Europe's springtime hopes had drooped, much to the dismay of Continental nationalists and their American sympathizers. ${ }^{26}$

Catholicism provided a convenient scapegoat for these republican failures, and soon revolutionary leaders renewed their rhetorical campaigns against the Church. Anticlerical sentiment already ran high among European socialists, who agreed with Karl Marx that organized religion numbed citizens to governmental abuse and prevented the leveling of society. Roman Catholicism's hierarchical power base, emphasis on obedience, fusion of church and state, and long-standing collusion with European monarchs cast the Church in an especially reactionary and illiberal light. ${ }^{27}$ Pius IX's "betrayal" of Italy provided political radicals with a telling example: after years of reformist and conciliatory rhetoric, the Pope showed his true colors by abandoning his homeland in the hour of its greatest need and allying with French and Austrian autocrats. Italian revolutionaries, eager to shift blame away from their own ineffective leadership and constant infighting, blamed priests for brainwashing peasants and undercutting republican sentiment. Nationalist mythology similarly flipped Catholic doctrine on its head by portraying Italian prisoners as Christ-like saviors who chose death so that their countrymen might live in freedom. Conspiracy tales proliferated across the Continent, further strengthening the strong anti-Catholic views that many 1848 exiles carried with them to their new Protestant havens in England and the United States. ${ }^{28}$

${ }^{26}$ Roberts, Distant Revolutions, 8-11; Light, Rome and the New Republic, 314; Steven Hughes, Crime, Disorder, and the Risorgimento: The Politics of Policing in Bologna (Cambridge: Cambridge University Press, 1994), 175-177.

${ }^{27}$ Levine, Spirit of 1848, 46-48; Isabella, Risorgimento in Exile, 98, 133, 204; John McGreevy, Catholicism and American Freedom: A History (New York: W.W. Norton, 2003), 20-24.

${ }^{28}$ D'Agostino, Rome in America, 23-32; McGreevy, Catholicism and American Freedom, 21-22; Honeck, We Are the Revolutionists, 20; Silvana Patriarca and Lucy Riall, eds., The Risorgimento Revisited (New York: Palgrave Macmillan, 2012), 4, 39-41, 50, 192; Howard Marraro, "The Religious Problem of the Italian Risorgimento 
These narratives contributed to a surge in transatlantic anti-Catholicism fueled by new demographics and old stereotypes. Memories of "Bloody” Queen Mary and Guy Fawkes remained alive and well in England, where popular traditions contrasted Catholic tyranny with Protestant republicanism. These views had also sailed west with Britain's North American colonists, who continued to mark Fawkes's downfall with Pope Day activities and other antiCatholic celebrations. France's crucial support during the American Revolution, coupled with the United States' small Catholic minority, temporarily silenced anti-Vatican sentiment in the Early Republic, but the mass influx of poor Irish immigrants who arrived on American, Canadian, and English shores in the 1830s and 1840s quickly renewed these prejudices. Laborers feared the economic fallout from these new arrivals, while authorities complained that Catholic voters were beholden to their bishops and unable to make independent choices at the ballot box. ${ }^{29}$ Anglo-American Protestants also took aim at Catholic spirituality, condemning the confessional and recoiling in terror from priestly celibacy and communal convent life. American preachers denounced Catholicism's unnatural ordained "families" and celebrated wholesome Protestant values, while popular sensationalist literature both embraced and subverted these ideals by providing "authentic" accounts of nunnery abortions and general clerical depravity. ${ }^{30}$ These tales, combined with reports of papal abuses in Europe and continuing sectarian conflicts in Canada, only stiffened Americans' resolve to resist all papal provocations at home and abroad.

as seen by Americans," Church History 25 (1956): 49; Rudolph Vecoli, "Prelates and Peasants: Italian Immigrants and the Catholic Church," Journal of Social History 2 (1969): 221-222.

${ }^{29}$ Anbinder, Nativism and Slavery, 3-9; Billington, Protestant Crusade, 1-35; McGreevy, Catholicism and American Freedom, 23-24; Radforth, "Political Demonstrations," 20; Horner, "Contesting Authority," 35; Walter Ralls, "The Papal Aggression of 1850: A Study in Victorian Anti-Catholicism," Church History 43 (1974): 242-245; Paul Gilje, The Road to Mobocracy: Popular Disorder in New York City, 1763-1834 (Chapel Hill: University of North Carolina Press, 1987), 25-26.

${ }^{30}$ Anbinder, Nativism and Slavery, 9; Billington, Protestant Crusade, 53-58, 92-102; Jenny Franchot, Roads to Rome: The Antebellum Protestant Encounter with Catholicism (Berkeley: University of California Press, 1994), 87-98, 117-145, 183; Sandra Frink, "Women, the Family, and the Fate of the Nation in American AntiCatholic Narratives, 1830-1860," Journal of the History of Sexuality 18 (2009): 237-264; Manuel Borutta, “AntiCatholicism and the Culture War in Risorgimento Italy," in The Risorgimento Revisited, eds. Patriarca and Riall, 191-201. 
When Vatican authorities closed in on Alessandro Gavazzi, for instance, the American viceconsul helped whisk the apostate priest out of Italy to safety in London. ${ }^{31}$

Protestants were further alarmed by the rapid spread of ultramontanism, a Catholic philosophical movement based on the writings of Thomas Aquinas that emphasized obedience to the papacy and devotion to the suffering Savior. Ultramontane priests and laymen on both sides of the Atlantic took aggressive stances against Protestant theology, bishops identified with Pius's political trials and instituted Roman Mass rites, and Church scholars claimed that Catholicism was the true source of trial by jury, habeas corpus, and other liberal hallmarks. ${ }^{32}$ Protestants scoffed at these suggestions, but the conversions of outspoken intellectuals such as America's Orestes Brownson and England's John Henry Newman caused many to fear that the spiritual balance of power favored Rome. By 1850, Catholicism appeared to be advancing on every front: the Pope was back in Rome, Irish bishops were gathering for their first national council in two hundred years, French sympathizers seemed to hold sway over the Canadian Parliament, and American bishops were remaking their national Church in Pius's image. ${ }^{33}$ The fate of both spiritual and political freedom, Protestant activists contended, hinged on a successful defense of Reformation ideology and theology against this coordinated papal onslaught. "Popery" could be

${ }^{31}$ Billington, Protestant Crusade, 123-131; Light, Rome and the New Republic, 319; Richard Shaw, Dagger John: The Unquiet Life and Times of Archbishop John Hughes of New York (New York: Paulist Press, 1977), 273; Bryan Le Beau, “'Saving the West from the Pope': Anti-Catholic Propaganda and the Settlement of the Mississippi River Valley,” American Studies 32 (1991): 101-114; Peter Guilday, lecture notes, folder 6, box 75, folder 4, box 103, Peter Guilday Papers, American Catholic History Research Center and University Archives, Catholic University of America (Washington, DC); Howard Marraro, "Italians in New York in the Eighteen Fifties, Part II," New York History 30 (1949): 276; Marraro, "Risorgimento," 41-48; Weekly Herald, June 16, 1849; June 11, 1853; June 18, 1853; Albany Evening Journal, August 10, 1849; Richmond Enquirer (Virginia), October 9, 1849; Baltimore Sun, June 13, 1853; Arkansas Whig (Little Rock), July 7, 1853.

${ }^{32}$ D'Agostino, Rome in America, 24, 32; McGreevy, Catholicism and American Freedom, 25-41; Peter Guilday, lecture notes, box 12, Peter Guilday Papers, American Catholic History Research Center and University Archives, Catholic University of America (Washington, DC).

${ }^{33}$ McGreevy, Catholicism and American Freedom, 43-44; Ralls, "Papal Aggression," 245-246, 251-252; Radforth, "Political Demonstrations," 2-3; Elinor Kyte Senior, British Regulars in Montreal: An Imperial Garrison, 1832-1854 (Montreal: McGill-Queen's University Press, 1981), 78-87. 
neither tolerated nor accommodated, for its continued presence would trigger the collapse of republican society. ${ }^{34}$

With Pius ensconced in the Vatican, the fight between ultramontanism and republicanism shifted to England and Wales, where a seemingly innocuous Church reorganization plan provoked protests from Protestant Britons. Despite its controversial Tudor past and current minority status, British Catholicism enjoyed unprecedented growth in the 1840s, buoyed by Irish immigration and an influential expatriate community in Rome. Encouraged by this success, Vatican leaders decided to abandon the country's missionary structure - headed by vicars who reported directly to the Holy See - in favor of a hierarchical organization in which bishops presided over geographical dioceses. Quebec and Australia had undergone similar shakeups without incident, but news of the Pope's September 29, 1850 decree struck a nerve in Protestants tired of changing demographics and sectarian squabbles. ${ }^{35}$ The London Times popularly dubbed the plan as "The Papal Aggression," seven thousand anti-Catholic meetings were organized by clerics and civic leaders, and Parliament later restricted the use of ecclesiastical titles by Catholic bishops. Protestant Britons were enraged by Pius's description of Anglicanism as a schismatic church and Nicholas Wiseman's appointment as Archbishop of Westminster, which was interpreted as a sinister reference to the seat of Parliament and British freedom. Catholics responded in true ultramontane style: John Henry Newman cheered the return of "authentic" Christianity to England, while Cardinal Wiseman's first pastoral letter described the celebration

\footnotetext{
${ }^{34}$ Anbinder, Nativism and Slavery, 24-27; Billington, Protestant Crusade, 173-193, 265-269; McGreevy, Catholicism and American Freedom, 36-37.

${ }^{35}$ Ralls, "Papal Aggression," 242-248; D.G. Paz, "Popular Anti-Catholicism in England, 18501851,"Albion 11 (1979): 331-333.
} 
in Heaven that accompanied the papal decree. ${ }^{36}$ With emotions running high, conspiratorial fears spreading, and compromise unlikely, the stage was set for a firebrand.

The "Aggression" provided a perfect cause célèbre for Alessandro Gavazzi to spend the following years traveling the Atlantic anti-Catholic lecture circuit railing against papal power. ${ }^{37}$ After fleeing his homeland, Gavazzi initially lived in poverty and obscurity in England until fellow exiles contracted him to present a series of lectures on "the errors and abuses of the Church of Rome, and the maladministration of the temporal government of the Pope.”38 Gavazzi’s impassioned pleas for Italian liberty caused an immediate sensation, and soon countless Britons, followed later by Americans and Canadians, flocked to hear the former priest and rhetoric professor. At each stop, Gavazzi skillfully appealed to his listeners' patriotism and Protestant propriety: in Britain, his lectures attacked the Papal Aggression and applauded London brewers for recently protesting the visit of Austrian counterrevolutionary Ludwig Haynau. The orator likewise began his Montreal lecture by praising Canada as "a true British country," while in the United States he abandoned these Old World references to extol exceptionalism and embrace nativist views on Irish immigration, Bible reading, and public schools. ${ }^{39}$ Beneath these constantly changing rhetorical positions, however, lay a central critique of the Church. Pius's pontificate represented a "monstrous intermarriage between the kingly function and the service of God's altar," he told British audiences in 1851, for "to combine both

\footnotetext{
${ }^{36}$ Ralls, "Papal Aggression," 243, 246-256; Paz, "Popular Anti-Catholicism," 334-336; The Leader and Saturday Analyst (London), December 28, 1850; London Examiner, September 7, 1850; The Home and Foreign Record of the Free Church of Scotland (Edinburgh), July 1, 1854.

${ }^{37}$ Horner, "Contesting Authority," 35-36.

38 “Italy, and Her Foremost Men," Sharpe’s London Journal, July 1851. See also Leader and Saturday Analyst, April 5, 1851; London Journal, April 26, 1851; Horner, "Contesting Authority," 35.

${ }^{39}$ Alessandro Gavazzi quoted in Horner, "Contesting Authority," 36; Marraro, "Italians Part II," 276; McGreevy, Catholicism and American Freedom, 24-25; Light, Rome and the New Republic, 319-320; Leader and Saturday Analyst, January 18, 1851; April 5, 1851; October 4, 1851.
} 
sacerdotal and regal excellence is a perfectly hopeless pretension." ${ }^{40}$ Men cannot serve both God and money, and neither could popes effectively manage administrative and spiritual demands. The Church's balancing act had failed: no railways ran through the Papal States, Gavazzi lamented, and residents were told to reject progress in favor of "infallible" truths. Christ avoided earthly power in order to protect His spirituality, Gavazzi reminded listeners, but Catholic leaders had since chosen worldly treasures over the Petrine ministry. ${ }^{41}$ For the sake of both national prosperity and spiritual orthodoxy, the Pope had to unequivocally relinquish his claims to governmental power.

While Gavazzi focused on the papacy's political shortcomings, most Protestants and Catholics interpreted his lectures as lively attacks on Church teachings. British newspapers focused on his exciting and dramatic style: "we honestly confess," one review declared, "that we have not seen or heard in London, any public orator at all to be compared with this finished and truly classic preacher." ${ }^{, 42}$ Reporters dealt at length on his calculated pauses, soaring rhetoric, impressive improvisations, and demonstrative behavior, universally praising Gavazzi’s appearance even though they barely understood his Italian diction. Translated synopses were available, but pious sectarian crowds remained transfixed by the spectacle on stage. ${ }^{43}$ Strikingly, Britons portrayed the lectures as entertainment, rarely linking Gavazzi to other popular 1848 exiles such as Giuseppe Mazzini and Louis Kossuth, who even then canvassed England for support. ${ }^{44}$ Gavazzi strengthened these views by stating that "Mazzini had a civil part to play,

\footnotetext{
${ }^{40}$ Leader and Saturday Analyst, January 18, 1851.

${ }^{41}$ Alessandro Gavazzi, The Lectures Complete of Father Gavazzi (New York: M.W. Dodd, 1854), 131-141, 305-315, 322, 353; Leader and Saturday Analyst, January 18, 1851.

${ }^{42}$ Leader and Saturday Analyst, January 18, 1851.

${ }^{43}$ Leader and Saturday Analyst, January 18, 1851; April 5, 1851; Light, Rome and the New Republic, 319.

${ }^{44}$ Gregory Claeys, "Mazzini, Kossuth, and British Radicalism, 1848-1854," Journal of British Studies 28 (1989): 225-227.
} 
[while] he had a religious part." 45 The apostate priest's apolitical popularity suited prominent ministers in the United States and Canada, who in 1853 invited him to denounce Catholicism across eastern North America. Large crowds turned out in New York and Baltimore to see the famous orator, while Catholic editors castigated him as a heretic. Soon this verbal abuse turned violent as enraged laymen attacked New York's Broadway Tabernacle during one lecture and pelted the church with bricks. Farther north, Canadian authorities nervously awaited Gavazzi's arrival, fearful that his presence would provoke far more than a few fistfights and broken windows. $^{46}$

These fears came to pass, as Gavazzi's northern tour enflamed civic tensions and disintegrated into bloody riots. Fierce conflicts were nothing new in Queen Victoria's colony, where forceful expressions of popular opinion were prized as examples of proper republican spirit. Canadian electoral campaigns routinely turned into physical battles, while religious differences were settled in the streets and British soldiers were often called upon to restore the civic peace. Troops quickly suppressed democratic uprisings in 1837 and 1838, but a decade later they had arrived too late to prevent an anglophone mob from burning Parliament in protest of legislation favoring French-Canadian residents. These British loyalists were motivated by fear and isolation: even in Her Majesty's own territory, francophone citizens enjoyed affluence and political influence, Irish immigrants roamed city streets with impunity, and ultramontane Catholics exerted considerable influence over colonial culture. Debates over Canada's future further split the populace, with some observers praising the status quo, others calling for full

\footnotetext{
${ }^{45}$ Leader and Saturday Analyst, October 4, 1851.

${ }^{46}$ D'Agostino, Rome in America, 33-34; Light, Rome and the New Republic, 319-320; McGreevy, Catholicism and American Freedom, 24-25; Marraro, "Italians Part II," 276-277; Horner, "Contesting Authority," 35-36; "Father Gavazzi," The Rambler (England), March 1852.
} 
independence, and still others agitating for American annexation. ${ }^{47}$ Gavazzi’s tour added more fuel to these raging political, religious, and ethnic rivalries. On June 6, 1853, his Quebec City lecture was interrupted by a predominantly Irish mob that charged into the Free Church of Scotland and assaulted the speaker and his associates. Policemen soon restored order and Gavazzi escaped the brawl with a few scratches, but three days later his appearance at Montreal's evangelical Zion Church took a tragic turn. Protestant churchgoers fired into the raucous crowd gathered outside, while British soldiers lost their nerves and opened fire in nearby Haymarket Square. Ten Catholic and Protestant citizens were killed and fifty wounded, the latest casualties of Canada's contentious search for civic order. ${ }^{48}$

Religious recriminations followed these riots, leaving both Catholics and Protestants to fashion sectarian narratives that blamed the violence on their misguided and overzealous opponents. Catholics held prejudiced ministers largely responsible for the riots: inviting such a controversial and apostate speaker as Gavazzi, they argued, had upset Canada's political culture and mocked the theological foundations of Roman Catholicism. Local prelates and Irish laymen contrasted their restraint and steely resolve with the violence of Gavazzi's supporters, while the Catholic True Witness vividly described lecture attendees as "the yahoos of Christianity."49 Protestants demurred, charging Catholics with trying to impose their unpopular views on free and rational citizens. On June 10, Quebec Protestants gathered at a mass meeting to defend their rights as Englishmen under the rule of Queen Victoria, the "Protestant Sovereign." At stake was no less than "the great principle which lies at the foundation of all true Protestantism," one

\footnotetext{
${ }^{47}$ Horner, "Contesting Authority," 29-36; Radforth, "Political Demonstrations," 2-5; Senior, British Regulars in Montreal, 24-27, 57-87; Philadelphia Public Ledger, July 20, 1849; Weekly Herald, April 28, 1849 ; August 4, 1849.

${ }^{48}$ Quebec Mercury, June 7, 1853; Morning Chronicle, June 7, 1853; June 9, 1853; June 10, 1853; June 11, 1853; Horner, "Contesting Authority," 29-31; Senior, British Regulars in Montreal, 109-122; Weekly Herald, June 11, 1853; June 18, 1853; Baltimore Sun, June 13, 1853; Daily Ohio Statesman (Columbus), June 14, 1853; Leader and Saturday Analyst, June 25, 1853; London Examiner, June 25, 1853.

49 True Witness quoted in Horner, "Contesting Authority," 36.
} 
minister explained, "the right of private judgment in matters of religion." ${ }^{50}$ After all, Quebec Protestants had recently remained peaceful and calm, despite their private objections, when American Catholic convert and "apostate minister" Orestes Brownson visited their city and publicly denounced his former coreligionists. ${ }^{51}$ Catholics, on the other hand, were victims of an intolerant Church that taught them to terrorize opponents and denounce diverse opinions. The rioters' stones had not been aimed at churchgoers or even Gavazzi himself, but rather at the principles of civic liberty and religious toleration. In the view of pro-British speaker Angus McDonald, Catholics resembled excitable children who barely understood the opportunities and privileges provided them by Protestantism. Since Gavazzi's critics “were objects of deep commisseration [sic], and slaves of a degrading system," he concluded, Canadian Protestants should "by kindness and forbearance ... try and make them good citizens." views underscored the fundamental critiques of Catholicism shared by British Protestants, agnostic European socialists, and apostate Italian friars: souls taught to obey could not coexist with minds taught to reason, and a Church that reigned in Europe could not possibly tolerate free governments elsewhere.

Yet the Gavazzi disturbances challenged civic views even as they reinforced religious divisions, causing many Canadians to question the meaning of responsive government. In Quebec, Angus McDonald praised British troops for protecting Canada from the chaotic revolutions that convulsed 1848 Europe, while his English-speaking Protestant neighbors complained that the police's lackadaisical preparations had allowed lawless Irish Catholics to attack Gavazzi with impunity. Preempting the crowds with a forceful display of British martial

\footnotetext{
${ }^{50}$ Quebec Mercury, June 11, 1853. See also the Morning Chronicle, June 11, 1853; Horner, "Contesting Authority," 36-52.

${ }_{51}$ Quebec Mercury, June 11, 1853.

${ }^{52}$ Quebec Mercury, June 7, 1853. See also the paper's June 11, 1853 edition.
} 
strength, the Quebec Mercury argued, would have surely quelled the agitators. ${ }^{53}$ Montreal residents were more gun-shy of garrison soldiers, however, for city leaders blamed the troops with escalating the Haymarket Square conflict and murdering innocent bystanders. ${ }^{54}$ Various military officers, along with Catholic Mayor Charles Wilson, were charged with ordering the fateful volleys - an accusation each man flatly denied. Newspaper editors remained especially skeptical of Wilson's protestations, but ultimately placed their faith in constitutional principles. "The law, and the rule of justice, and of honor, is impartial," the Montreal Transcript declared, for "we have no doubt that the magistrates ... will, at common law, on deposition, commit the parties accused of so dreadful a crime." 55 Gavazzi returned to the United States on June 11, but public interest remained high in the Montreal coroners' inquest, which ended a month later with a divided jury. Military leaders proceeded to hold a court of inquiry, only to drop the matter soon afterwards. English-speaking newspapers were outraged by this apparent miscarriage of justice, while Montreal residents called for an end to military interventions and an expansion of the city's civilian police force. Foreshadowing another Italian priest's riotous welcome to North America, these civic conflicts forced Canadians to confront the contested meanings of political dissent, free speech, law and order, and police overreach. ${ }^{56}$

Across the border, American editors construed these debates to strengthen faith in their nation's exceptionalism. When British loyalists complained that Irish Catholics were illiberal juveniles, editors in New York, Baltimore, and even Arkansas retorted that most of the colony's residents were excitable adolescents who lacked the discipline, knowledge, and experience

\footnotetext{
${ }^{53}$ Quebec Mercury, June 7, 1853. See also the Morning Chronicle, June 7, 1853.

${ }_{54}^{5}$ Senior, British Regulars in Montreal, 116-121; Horner, "Contesting Authority," 30-31.

${ }_{55}$ Montreal Transcript quoted in the Quebec Mercury, June 14, 1853.

${ }^{56}$ Senior, British Regulars in Montreal, 120-133; Horner, "Contesting Authority," 49-52.
} 
needed for peaceful republican society. ${ }^{57}$ In the wake of Montreal's 1849 Parliament Riot, a Philadelphia editorial had noted that "Canadians have a great many ridiculous prejudices to remove before they will be able to enjoy in their excellence the blessings of [American] annexation." ${ }^{58}$ Four years later, the colony still seemed mired in sectarian, ethnic, and political strife. Detailed accounts of the Quebec City and Montreal disturbances quickly spread across the United States, accompanied by lengthy editorials denouncing mob rule as well as the radical rhetoric of both Gavazzi and his critics. True Americans abhorred Gavazzi's extremist and vengeful views, the Baltimore Sun noted, but proper republican restraint kept these private views from spilling out into the streets. Indignant residents similarly flocked to Gavazzi's post-riot rallies in New York City, the Tribune argued, not to support his message, but rather to testify to the republican virtues of religious liberty and constitutionalism. "What the law allows," Baltimore writers solemnly declared, "the citizen must not prevent." ${ }^{60}$ Ironically, these nationalist odes to free government and the rule of law invoked the same values and rhetoric employed by Canadian Protestants, all the while ignoring continued ethnic and religious tensions in the United States. ${ }^{61}$

Gavazzi spun similar tales to further nationalist aims and portrayed himself as an embodiment of virtuous republican resistance. While Canadian Protestants celebrated the lecture attendees' democratic decorum and American narratives asserted national superiority by denigrating colonial demagogues, Gavazzi's correspondence presented the Quebec Riot as a metaphor for his homeland's fight for freedom. American, British, and Canadian newspapers

${ }^{57}$ Weekly Herald, June 11, 1853; Baltimore Sun, June 13, 1853; Mississippi Free Trader (Natchez), June 14, 1853; Arkansas Whig, July 7, 1853.

${ }_{58}^{58}$ Philadelphia Public Ledger, July 20, 1849.

${ }^{59}$ Baltimore Sun, June 13, 1853; New York Tribune quoted in Marraro, "Italians Part II," 278.

${ }^{60}$ Baltimore Sun, June 13, 1853.

${ }^{61}$ Roberts, Distant Revolutions, 15-20, 56-58; Gemme, Domesticating Foreign Struggles, 5, 16, 46, 73 , 107; Fenton, "Birth of a Protestant Nation," 29-50; Adam Tuchinsky, Horace Greeley's 'New York Tribune': Civil War-Era Socialism and the Crisis of Free Labor (Ithaca, NY: Cornell University Press, 2009), 88-94. 
quickly reprinted these fantastical observations, but overlooked their allusions to Continental betrayal, conspiracy, and resistance. ${ }^{62}$ For instance, Gavazzi insisted that the Quebec City police had stood idly by, like Pope Pius, as unkempt ruffians - who resembled impoverished and superstitious Italian peasants - charged through the church doors. The attackers first tried to extinguish the lights so as to conceal their movements, assassinate Gavazzi, and hold members of the crowd as hostages, but these plans were derailed by their inability to turn off the church's gas valve. Undeterred, sixty brawlers headed straight for the pulpit, where they were forcefully met by one honest policeman, Gavazzi's secretary, and the lecturer himself. For over twenty-five minutes, these three men supposedly held off the assailants: "I took off my cloak," Gavazzi recounted, "and brandishing the chair which had served me as an orator, I defended my post, as a true Italian crusader."63 The policemen's continued inaction allowed the sanctuary to swell with over seven hundred rioters, who eventually overpowered the lecturer and sent him tumbling off the pulpit. Despite this life-threatening fall, Gavazzi, like countless other republican exiles before him, bounced to his feet and, with "a gigantic effort," managed to find sanctuary in a Sunday school classroom until Her Majesty's troops arrived. ${ }^{64}$ Chased and scorned by the very crowds who should have welcomed his message of national freedom and spiritual liberation, Gavazzi pointedly found refuge not with his former coreligionists, but with British loyalists. This exaggerated account allowed Gavazzi to appeal to public sympathy and standard anti-Catholic stereotypes, parlaying domestic frustration over increased immigration and civic disorder into support for his dreams of a democratic Italy.

${ }^{62}$ Morning Chronicle, June 7, 1853; Baltimore Sun, June 13, 1853; Daily Ohio Statesman, June 14, 1853; Leader and Saturday Analyst, June 25, 1853; Horner, "Contesting Authority," 44; Light, Rome and the New Republic, 320.

${ }^{63}$ Baltimore Sun, June 13, 1853.

${ }^{64}$ Ibid. 
Gavazzi’s eulogies of fellow revolutionary chaplain Ugo Bassi epitomized his efforts to refashion political setbacks into pious tales of heroic endurance and republican sacrifice. In life, Bassi had been one of Italy's most prominent revolutionary spokesmen, but in death the young priest was elevated to the status of nationalist martyr. Gavazzi seemed to relish his new role as Bassi's evangelist, narrating his friend's life and trials to audiences on both sides of the Atlantic. ${ }^{65}$ Bassi had been a linguist, musician, orator, and poet, Gavazzi told New Yorkers in 1853, a man without sinful blemish, superstition, or prejudice. A passionate believer in Italian independence, he never strayed far from the front lines, always ministering to soldiers and defying the forces of tyranny. "O beloved and generous Bassi!" Gavazzi cried, "thy memory will ever be dear to Italian hearts, and thy name will be blessed and venerated wherever is honored the blood shed for country, for religion, and for God!" 66 Having established the friar's messianic credentials, Gavazzi turned to Bassi’s Christ-like demise: captured by Austrian troops in 1849, the Bologna native was betrayed by religious leaders in his hometown, brutally tortured, and soon led before a firing squad. The friar's final moments seemed straight out of the Gospels, complete with descriptions of his grieving mother and accounts of an Austrian officer weeping for his innocent victim. Shot in the chest, Bassi lingered just long enough to cry out for both his Father and fatherland: "Honor and glory to Jesus," he gasped, "liberty and prosperity to Italy!"67 Gavazzi's moral was clear: through the sacrifices of Bassi and others, the Roman Republic would soon be resurrected. The villains of Bassi's passion play were equally apparent: Austrians

${ }^{65}$ Adrian Lyttelton, "The Hero and the People," in The Risorgimento Revisited, eds. Patriarca and Riall, 41; Gavazzi, "Lectures," xxiii, 363. Tellingly, Gavazzi's first speech in London was a funeral oration for Bassi. See "Italy and Her Foremost Men," Sharpe's London Journal, July 1851; Leader and Saturday Analyst, April 5, 1851; London Journal, April 26, 1851.

${ }^{66}$ Gavazzi, "Lectures," xxiii.

${ }^{67}$ Ibid., 363. 
replaced Pilate and his centurions, while Gavazzi's American lectures identified Caiaphas as Bologna’s former papal commissioner, Archbishop Gaetano Bedini. ${ }^{68}$

Gavazzi’s claims promised to complicate Bedini’s already contentious American visit, which was marred from the start by miscommunication and mistrust. Accredited as the apostolic nuncio to Brazil, Bedini was first directed by Vatican officials to report on conditions in the United States before heading to his official post in Rio de Janeiro. Strengthening relations with the U.S. government, surveying the state of the American Church, counseling bishops, and arbitrating Buffalo's trustee debate filled out Bedini's agenda, but Rome made only halting efforts to apprise American prelates of his ecclesiastical mission or clarify the Nuncio's temporal status with elected officials. Armed with little more than a complimentary letter from Pius IX to President Franklin Pierce and assurances from the U.S. chargé in Rome, Lewis Cass, Jr., that he was welcome in America, Bedini arrived in New York on June 30, 1853. Gavazzi's return from Montreal and the arrival of over eighty Sardinian political exiles preceded the Nuncio's appearance, yet surprisingly he attracted scant attention outside of Church circles. ${ }^{69}$ Lay Catholics rejoiced at the Nuncio's arrival and eagerly sought his apostolic blessing, even as some bishops privately grumbled about their mysterious visitor. From the start, Bedini's Brazilian accreditation seemed like a convenient cover story for his real investigative and diplomatic duties. St. Louis Archbishop Peter Kenrick complained that the Nuncio’s visit was “anything but agreeable, being one thing in appearance and another in effect," while his brother Francis, the Archbishop of Baltimore, doubted Bedini's intentions: "although his Nunciature is nominally to the Court of Brazil, he is a special envoy to the United States, which I conjecture, is his real

\footnotetext{
${ }^{68}$ Hughes, Politics of Policing, 204, 207, 220; Connelly, Visit of Archbishop Gaetano Bedini, 289-290.

${ }^{69}$ Connelly, Visit of Archbishop Gaetano Bedini, 4-19; Endres, "Reassessing the Visit," 5-6; Shaw, Dagger John, 279-280; Timothy Dolan, “'Hence We Cheerfully Sent One Who Should Represent Our Person': A Century of Papal Representation in the United States," U.S. Catholic Historian 12 (1994): 3-4.
} 
mission." ${ }^{70}$ Some independent-minded prelates feared that Bedini's mission amounted to a Roman audit of the American Church, priests remained in the dark concerning the Nuncio's travel plans, and as July turned to August, citizens began wondering why the Archbishop still tarried in the United States. ${ }^{71}$ And then, just as Gavazzi began identifying Bedini as Bologna's "Butcher," the Nuncio sailed straight into his first American controversy. National editorials sharply condemned Bedini's August 1853 voyage on the naval steamer U.S.S. Michigan, igniting a fierce debate over the limits of secular government and republican hospitality. After greeting laymen and prelates across the East Coast, Bedini had headed west in late July to consecrate Milwaukee's new Cathedral of St. John alongside his friends, New York Archbishop John Hughes and Cincinnati Archbishop John Purcell. Their duties complete, Bedini and Hughes next inspected Native American missions before stepping aboard the Michigan for passage to Detroit. As soon as Bedini debarked, however, the Detroit Tribune reprimanded the ship's captain for colluding with papal despotism, using federal funds to transport the Archbishop, and providing the unaccredited Nuncio with a diplomatic salute. Accusations and denials flew in every direction: Catholics claimed that the Pierce Administration

${ }^{70}$ Archbishop Peter Kenrick and Archbishop Francis Kenrick quoted in Shaw, Dagger John, 279, and Connelly, Visit of Archbishop Gaetano Bedini, 21, respectively. Even Bedini's diplomatic card announced that he was "en mission extraordinaire auprés du gouvernement des Etats-Unis" (Connelly, Visit of Archbishop Gaetano Bedini, 21). The Nuncio used French for two reasons. First, it was, along with Latin, the official diplomatic language of the Holy See (David Gerber, "Modernity in the Service of Tradition: Catholic Lay Trustees at Buffalo's St. Louis Church and the Transformation of European Communal Traditions, 1829-1855," Journal of Social History 15 (1982): 661). More importantly, he was fluent in French but could barely speak English (Shaw, Dagger John, 280). For early coverage of Bedini's mission and popular reception, see Connelly, Visit of Archbishop Gaetano Bedini, 19-21; Archbishop Gaetano Bedini, letter to Archbishop John Purcell, July 21, 1853, Archdiocesan Records, Electronic Archival Calendar, University of Notre Dame Archives (Notre Dame, Ind.); Baltimore Sun, June 26, 1853; Boston Daily Evening Transcript, July 7, 1853; New Orleans Daily Picayune, July 9, 1853; July 12, 1853; July $15,1853$.

${ }^{71}$ Archbishop John Purcell, letter to Father Etienne Rousselon, July 14, 1853, Archdiocesan Records, Electronic Archival Calendar, University of Notre Dame Archives (Notre Dame, Ind.); Archbishop Anthony Blanc, letter to Archbishop John Purcell, July 27, 1853, Archdiocesan Records, Electronic Archival Calendar, University of Notre Dame Archives (Notre Dame, Ind.); Father John McCaffrey, letter to Archbishop John Purcell, September 15, 1853, Archdiocesan Records, Electronic Archival Calendar, University of Notre Dame Archives (Notre Dame, Ind.); Light, Rome and the New Republic, 322-323; Mairose, "Nativism on the Ohio," 63. 
had directed the Michigan to ferry Bedini as a sign of goodwill, just as American sailors earlier transported Louis Kossuth from Constantinople to England and the United States. Editorialists in New York and Washington claimed that the captain had exceeded his orders and embarrassed President Pierce, while the Detroit Free Press praised these welcoming gestures. ${ }^{72}$ Competing papers picked up Gavazzi's accusations, while native-born Americans struggled to disaggregate the Nuncio's spiritual and temporal duties. The Free Press concluded that Bedini's status as a dignified foreign visitor entitled him to a respectful welcome, but others claimed that the Archbishop's mission, let alone his murderous misdeeds, excluded him from diplomatic immunity. Philadelphia writers termed the Nuncio's tour “entirely ecclesiastical," while Washington's National Era bluntly asked, “is he [Bedini] not merely a spiritual envoy from the Pope?"73 These debates exposed conflicting memories of the 1848 revolutions and foreshadowed national arguments over Bedini's temporal authority, providing immigrants and native-born republicans with further "evidence” of Rome's disregard for constitutionalism.

Bedini's Great Lakes tour energized political exiles in Milwaukee, who matched Gavazzi's nationalist rhetoric with sensationalist tales of Continental butchery and deceit. Answering the New York L'Eco d'Italia's call "to expose the wolf [Bedini] who had crept in dressed in sheep's clothing," German leaders denounced the emissary while praising Bassi as the father of Italian unity. ${ }^{74}$ The Milwaukee Daily Sentinel quickly rose to the Archbishop's defense by publishing a supposedly authoritative account of his Bologna tenure, only to have Gavazzi pen a forceful rebuttal. "I wish the reader to observe the Jesuitical, foxy character of the whole article," the former friar retorted, "for it is written with such art that if its authors were called up

\footnotetext{
${ }^{72}$ Connelly, Visit of Archbishop Gaetano Bedini, 16-33; Shaw, Dagger John, 281.

${ }^{73}$ Philadelphia North American, August 22, 1853; National Era, August 25, 1853. See also Connelly, Visit of Archbishop Gaetano Bedini, 32.

${ }^{74}$ L'Eco d'Italia quoted in Marraro, "Italians Part II," 280. See also Connelly, Visit of Archbishop Gaetano Bedini, 30-36; Milwaukee Daily Sentinel, August 19, 1853.
} 
in judgment before a Court, they might take an oath that it is true in all its parts, although, instead of this, it is totally false." 75 The anonymous Milwaukee editorialist "C" shot back that Italy's revolutionary troops had been ruffians, murderers, and liars bent on terrorizing Rome. Two days later, "E" responded that "C" was a papal sympathizer whose religious devotion blinded him to Italy's impoverished and illiberal realities. ${ }^{76}$ Not to be outdone, Gavazzi denounced all his critics as depraved papists and conveniently forgot that he had spent years telling Britons that the Austrians were to blame for Bassi's death. With the Nuncio in his rhetorical sights, the former priest now insisted that he had always considered Bedini as "the Butcher of Ugo Bassi.",77 The Daily Sentinel had long since bowed out of the heated debate, weakening the exiles' efforts to garner public support for republican reforms. ${ }^{78}$ But still the recriminations continued, fueled by Gavazzi’s bombastic rhetoric, old grudges, and growing fears of Catholic political interference. Pent-up revolutionary frustrations led Italian exiles to plot Bedini's downfall, but their failed efforts only strengthened the Nuncio's ultramontane beliefs. In 1848, Pope Pius reacted to similar backlash against his Austrian allocution by appointing Pellegrino Rossi as chief minister of the Papal States. Rossi's loyalty to the Vatican pleased the Holy Father but angered political radicals, and on November 15, assailants slit the minister's throat in broad daylight. Guardsmen made no effort to apprehend the assassins as radicals cheered their enemy's demise, igniting the

\footnotetext{
${ }^{75}$ Milwaukee Daily Sentinel, September 2, 1853. Emphasis original. Gavazzi's obsessive quest for "evidence" of papal conspiracies, along with his definition of the Jesuit "other" and his use of broad conspiratorial narratives that explained evil in the world, were all consistent with the paranoid political cultures of both Italy and the antebellum United States. See Paul Ginsborg, "European Romanticism and the Italian Risorgimento," in The Risorgimento Revisited, eds. Patriarca and Riall, 28; Michael Pfau, The Political Style of Conspiracy: Chase, Sumner, and Lincoln (East Lansing: Michigan State University Press, 2005), 1-13.

${ }^{76}$ Milwaukee Daily Sentinel, September 5, 1853; September 7, 1853.

${ }^{77}$ Milwaukee Daily Sentinel, October 20, 1853. Emphasis original. While Gavazzi claimed to have always blamed Bassi's death on Bedini, earlier English newspapers reported that he blamed Bassi's death on the Austrians. See Leader and Saturday Analyst, April 4, 1851; London Journal, April 26, 1851.

${ }^{78}$ Milwaukee Daily Sentinel, September 5, 1853.
} 
series of demonstrations that forced the Pope into temporary exile. ${ }^{79}$ Five years later, prelates and republicans staged a sequel to the Rossi Affair on the streets of New York City: Sardinian refugees, enraged by the arrival of Pius's personal representative, were rumored to be conspiring against Bedini. One repentant refugee alerted Archbishop John Hughes, but within a week the informant had been stabbed to death, his murder never solved by city police. ${ }^{80}$ A panicked local priest notified Bedini of these troubling events, but the Nuncio calmly responded from Canada: "my life is in the hands of God ... my heart is for loving even those that [sic] hate me." Archbishop Hughes blamed "Gavazzi and a few Italian desperadoes" for the commotion and boldly urged Bedini to continue his journey without interruption. ${ }^{82}$ The Nuncio agreed, transforming the meaning of his visit from a diplomatic journey into a spiritual exercise. Bedini further promised to never abandon American Catholics but rather share in their sufferings and protect them from all harm. ${ }^{83}$ Undeterred by the prospect of martyrdom, Bedini redoubled his efforts to reconcile the fallen world with the truths revealed by Church teachings.

Bedini's traditionalist crusade was set on a collision course with the democratic parishioners of Buffalo's St. Louis Church, who had vexed the American Catholic hierarchy for over a decade. Founded in 1829, St. Louis was Buffalo's oldest Catholic parish and a noted Alsatian and German cultural center, an attribute that brought its members into constant conflict with their Irish-American bishops. Like many parishes in the Early Republic, St. Louis initially boasted a lay trustee board that oversaw its temporal property, finances, and secular employees.

\footnotetext{
${ }^{79}$ Roberts, Distant Revolutions, 8-9; Coppa, Pius IX, 87-94. Rossi was officially known as minister of interior for the Papal States, but this position made him the de facto prime minister.

${ }^{80}$ Connelly, Visit of Archbishop Gaetano Bedini, 38-39; Shaw, Dagger John, 282-283.

${ }^{81}$ Archbishop Gaetano Bedini, letter to Father Anthony Cauvin, September 20, 1853, quoted in Connelly, Visit of Archbishop Gaetano Bedini, 39.

${ }^{82}$ Archbishop John Hughes, letter to Reverend Bernard Smith, November 25, 1853, Archbishop John Hughes Papers, American Catholic History Research Center and University Archives, Catholic University of America (Washington, DC).

${ }^{83}$ Archbishop Gaetano Bedini, letter to Archbishop John Purcell, October 22, 1853, Archdiocesan Records, Electronic Archival Calendar, University of Notre Dame Archives (Notre Dame, Ind.).
} 
But while most churches drew on Protestant trustee examples, St. Louis's democratically-elected board was modeled on European precedents. When surrounding parishes later bowed to ultramontane pressure to surrender lay prerogatives and title all parish properties in the name of the diocesan bishop, St. Louis parishioners flatly refused. Their rebuttal referenced both Old and New World cultures, citing European parish management bodies and their current incorporated status under New York state law. These arguments fell on the deaf ears of Archbishop John Hughes, however, who initiated a decade-long cycle of interdicts, reconciliations, and arguments that by 1853 had left St. Louis without a pastor and under the constant threat of excommunication. Hughes unsuccessfully sought to stave off growing Protestant sympathy for the trustees by supporting state legislation that would allow prelates to hold title to parish property, but over four hundred parishioners retorted by signing a petition asking Pope Pius IX to personally ensure their ecclesiastical rights. In response, unmoved Vatican officials directed Bedini to quell the St. Louis rebellion during his American stay. ${ }^{84}$

The Nuncio's subsequent denial of trustee rights dismayed Protestant onlookers, who criticized the Church's seemingly medieval views of secularism and salvation. After meeting with the trustees and Buffalo Bishop John Timon, Bedini issued his ruling against the St. Louis parishioners on October 25, 1853. Neither the church's legal deed nor charter supported the trustees' claims, the Nuncio announced, and continued resistance to legitimate episcopal authority would only endanger the parishioners' eternal futures. "You, of course, can submit to or refuse my declaration," Bedini noted, "but the Catholic Church is also free to recognize those that are her true children . . . it is time to make peace and to return to the vineyard of the Lord." ${ }^{\circ 5}$

\footnotetext{
${ }^{84}$ Bedini's original directions from the Vatican specifically ordered him to arbitrate the St. Louis debate. See Connelly, Visit of Archbishop Gaetano Bedini, 13, 50-56; Gerber, "Modernity in the Service of Tradition," 655676; Shaw, Dagger John, 187-188, 202; Light, Rome in the New Republic, 321-322.

${ }^{85}$ Archbishop Gaetano Bedini quoted in Connelly, Visit of Archbishop Gaetano Bedini, 64.
} 
The Alsatian and German parishioners lambasted Bedini as a foreign agitator and insisted that they had "no objection ... to the control of the Bishop and the Priest in spiritual things" so long as they were left to "manage their own temporalities." $" 86$ Protestants and exiles were heartened by this "bold and praiseworthy stand" of the "brave St. Louisers," who were portrayed as foot soldiers in the republican fight against Catholic autocracy. ${ }^{87}$ All mention of the trustees' European traditions and continued spiritual orthodoxy was lost amidst these rhetorical reaffirmations of exceptionalism and republicanism. After reminding readers of the Catholic Church's tenacious hold on European temporal power, for instance, the Baltimore Patriot called on Bishop Timon to place the case before the courts rather than act as the arbitrary judge of laymen's souls. ${ }^{88}$ While Bedini, Hughes, and Timon prized the prerogatives of apostolic succession, critics charged that these ossified hierarchies violated the public's right to private judgment in political and religious matters.

Theocratic fears also dogged Bedini's continuing efforts to receive official diplomatic recognition in the United States, as federal officials remained wary of acknowledging the Nuncio's joint temporal and spiritual roles. President Franklin Pierce had respectfully welcomed Bedini to Washington in early July 1853, but Gavazzi's subsequent harangues, strong nativist sentiment, and popular fallout from the Michigan scandal led his Administration to distance itself from the controversial Archbishop. Secretary of State William Marcy issued Bedini a standard passport but refused to grant him diplomatic status or immunity, given his Brazilian accreditation and the United States' long refusal to acknowledge Pope Pius as "head of the church."

\footnotetext{
${ }^{86}$ The Constitution (Middletown, Conn.), November 9, 1853. See also Connelly, Visit of Archbishop Gaetano Bedini, 65-73; Gerber, "Modernity in the Service of Tradition," 674-675.

${ }^{87}$ Weekly Herald, July 1, 1854 and Buffalo Demokrat, October 22, 1853, respectively, quoted in Connelly, Visit of Archbishop Gaetano Bedini, 51.

${ }^{88}$ Baltimore Patriot quoted in the Arkansas Whig, July 27, 1854.

${ }^{89}$ Vermont Journal (Windsor), February 3, 1854. See also Weekly Herald, January 28, 1854; Connelly, Visit of Archbishop Gaetano Bedini, 18.
} 
Archbishop John Hughes's lobbying efforts were met with similar rebuffs, as Catholic Postmaster General James Campbell explained that the federal government was not prepared to establish full diplomatic relations with the Papal States. President Pierce was open to the idea of establishing an official Vatican embassy, or nunciature, in the United States, but again the principles of religious liberty and nonsectarian government remained paramount. "The President will receive a Chargé or Minister from the Pope," Campbell explained, "but he can only of course, be received as his political representative. If His Holiness were to appoint a layman, there would be no difficulty in receiving him." 90 Campbell's analysis proven prescient, for the United States would not welcome an accredited apostolic nuncio, representing both the temporal Vatican and spiritual Holy See, for another one hundred and thirty years. In Bedini's day, Pius's reactionary reputation, changing demographics, spiritual squabbles over Church "superstition," and most importantly, popular insistence on the separation of sectarian religion from state affairs, all conspired against the Nuncio's diplomatic aspirations. ${ }^{91}$

Archbishop Hughes reflexively reacted to these concerns by reiterating ultramontane descriptions of the Church as both an earthly institution and spiritual communion. In direct contrast to Italian and Protestant critics, who described the Papal States as a perversion of the Vatican's ecclesiastical mission, Hughes insisted that these land holdings ensured the Holy See's spiritual independence. Not only had God ordained for the Pope to rule Rome, Hughes argued, but territorial sovereignty allowed the Holy Father to preach the authentic Gospel message without fear of earthly interference. "If he [the Pope] were the subject of any government," the New York Archbishop asked in 1850, "how could he freely speak the truth?"92 In a similar vein,

\footnotetext{
${ }^{90}$ Postmaster General James Campbell, letter to Archbishop John Hughes, December 22, 1853, quoted in Connelly, Visit of Archbishop Gaetano Bedini, 80.

${ }_{91}$ Dolan, "Century of Papal Representation," 3-4, 22.

92 Archbishop John Hughes quoted in Shaw, Dagger John, 244. See also Marraro, “Risorgimento,” 47-48.
} 
Hughes brushed off Postmaster General Campbell's vague reply but still insisted that an American nunciature would help protect the Church's finances and land holdings from abuse and governmental incursion. Unfortunately, the Archbishop lamented, Bedini's vague accreditation and Gavazzi's lies would prevent the capable Nuncio from accepting this important assignment. $^{93}$

Popular narratives and growing opposition to Bedini's visit ultimately reinforced liberal views of faith and politics even as they revealed contrasting interpretations of church and state. To many American, British, and Canadian Protestants, Pius's handling of the 1848 crises - as well as the Church's ultramontane leanings - exposed Catholicism as an oppressive, reactionary, and intolerant institution whose insistence on governmental influence and spiritual homogeneity contradicted the principles of liberal modernity. At its core, midcentury transatlantic antiCatholic thought centered on political concerns. Protestant and secular opponents both claimed Catholicism's foreign nature, supposedly “infallible” teachings, and temporal power all opposed republican values. Citizens could not simultaneously embrace democratic and dogmatic truths; while the teachings of Luther and Calvin fostered inquiry, economic development, and rationalism, Pius's minions corrupted governments and remained obsessed with orthodoxy. As for proof of Catholicism's inability to absorb criticism, observers looked no further than antiGavazzi mobs and Bedini’s opposition to the "heretical" trustees of St. Louis. For AngloAmerican observers and discontented European exiles such as Gavazzi, democracy and Catholicism appeared to be mutually exclusive systems. As historian Rudolph Vecoli noted, “it was difficult to be both an Italian patriot and a faithful Catholic." 94 Most public cries for religious liberty, whether originating from exaggerated or exceptionalist sources, thus reflected

\footnotetext{
${ }^{93}$ Archbishop John Hughes, letter to Dr. Tobias Kirby, August 10, 1854, quoted in Connelly, Visit of Archbishop Gaetano Bedini, 80-82.

${ }^{94}$ Vecoli, "Priests and Peasants," 222.
} 
the desire to wall off Catholicism, rather than religious faith more generally, from the public sphere. Yet Gavazzi's calls for disestablished religion were not enough for European socialists, who demanded a strict separation between Christian principles and democratic government. In Cincinnati, these agnostic views led to conflict between German Freemen and faithful Protestants - until shared concerns over republicanism and the rule of law, as represented by the specter of Gaetano Bedini, provided common ground between immigrant and native-born residents. 


\section{Chapter Two}

\section{Free Speech or Violent Insurrection? Political and Rhetorical Reactions to the Cincinnati "Bedini Affair"}

After months of travel and public opposition, a weary Archbishop Bedini arrived along the banks of the Ohio River in December 1853 to celebrate Christmas with Cincinnati Archbishop John Purcell. Since being introduced in Vienna in 1838, during one of the Ohio prelate's many ecclesiastical and fundraising trips to Europe, Bedini and the Irish-born Purcell had carried on an extensive transatlantic correspondence. Both men eagerly awaited their reunion, but Bedini's ever-changing itinerary and growing sense of responsibility for American Catholics delayed his visit until winter. By then, Alessandro Gavazzi’s tales had circulated among members of Cincinnati's German Freemen society, who denounced the visiting "Butcher of Bologna." The exiles' radical Hochwächter newspaper demanded vengeance against Bedini, the vicious foe of republicanism, but native-born Cincinnatians were preoccupied by holiday preparations and largely ignored these foreign pronouncements. Bedini and Purcell's tour of local Catholic schools and charities consequently went off without incident, as did Christmas Mass at St. Peter's Cathedral on Sunday, December 25, 1853. Plagued by a sore throat, the Nuncio retired to bed early that evening, just as Freemen and police collided in a nighttime clash that exposed the conflicting meanings of Bedini's American tour. ${ }^{95}$

\footnotetext{
${ }^{95}$ Mairose, "Nativism on the Ohio," 69-72; Sister Mary Agnes McCann, "The Most Reverend John Baptist Purcell, D.D., Archbishop of Cincinnati (1800-1883)," The Catholic Historical Review 6 (1920): 172; Father Gaetano Bedini, letters to Bishop John Purcell, August 9, 1846; December 18, 1846; December 6, 1847 , Archdiocesan Records, Electronic Archival Calendar, University of Notre Dame Archives (Notre Dame, Ind.); Archbishop Gaetano Bedini, letters to Archbishop John Purcell, July 21, 1853; October 22, 1853; December 17, 1853, Archdiocesan Records, Electronic Archival Calendar, University of Notre Dame Archives (Notre Dame, Ind.); Archbishop John Purcell, letter to Archbishop Anthony Blanc, December 30, 1853, Archdiocesan Records, Electronic Archival Calendar, University of Notre Dame Archives (Notre Dame, Ind.).
} 
These German protestors were no strangers to local controversy, since their Enlightenment-inspired faith in socialism and human reason brought them into constant conflict with Cincinnati political elites. To Democratic officials, the city's Freimännerverein posed a grave threat to American republican virtue and civic law and order. Founded in 1850 as part of a nationwide effort to unite German-American socialists inspired by the legacies of 1848, the Freemen aimed to reform city life by confronting corruption, contesting slavery and inequality, and calling for direct elections, expanded suffrage, and increased governmental intervention in the economy. Upon arriving in the United States, many of these émigrés believed that their new nation's Constitution and popular love of liberty promoted egalitarian beliefs. Instead, in New York, Boston, Cleveland, Cincinnati, and other German-American cultural centers, exiles were rebuked by nativists, distrusted by Whigs and Democrats, and shunned by more established immigrant families, all of whom saw the Freemen as conniving and hotheaded radicals bent on transforming America into a socialist state. ${ }^{96}$ Before 1848, many immigrants and Whigs boasted socialist sympathies, but in the wake of Europe's revolutionary bloodbaths, voters and politicians quickly changed their tunes. Now, American restraint and civic peace were praised as exceptional values, while calls for full equality and fraternity were compared to cries for wanton terror and radical violence. ${ }^{97}$

Native-born residents were also concerned by the Freemen's Sunday political rallies and rationalist theology, since nonsectarian Christianity still served as the hallmark of America's virtuous, hierarchical, and peaceful society. While German exiles interpreted Enlightenment philosophy as a call to buck organized religion's priestly tyranny, many native Cincinnatians subscribed to the popular antebellum view that "freedom of religion" ideally meant the freedom

\footnotetext{
${ }^{96}$ Levine, Spirit of 1848, 96-98; Honeck, We Are the Revolutionists, 21-28, 75-76.

${ }^{97}$ Tuchinsky, 'New York Tribune,' 21-49, 81-99; Roberts, Distant Revolutions, 15-20.
} 
to practice one's preferred brand of Protestantism. ${ }^{98}$ Not surprisingly, the Freemen's claim to freedom from religion shocked Catholics as well as members of proper Cincinnati society, who described the new arrivals as lawless "infidels." Since these émigrés were unrestrained by Christian charity and obedience, native-born residents feared, they were liable to become anarchists. ${ }^{99}$ The Freemen demurred, arguing that organized sects should focus on competing for souls rather than fighting for political influence. ${ }^{100}$ In the exiles' view, collusion between church and state, even in the name of ensuring republican virtue, only produced tyranny. Gavazzi's descriptions of Bolognese depravity found willing listeners in Cincinnati; unlike their neighbors, the Freemen refused to acquiesce to religious autocracy and terror. ${ }^{101}$ "The opportunity for revenge" against the Nuncio, the Hochwächter announced before Christmas, "should be taken hold of and used to the utmost." 102 The Freemen soon busied themselves in preparation for an anti-Bedini "protest," even as native Cincinnatians remained primed to view any socialist "provocation" as an attack on cherished American principles.

These opposing views of democracy collided on Christmas, producing a deadly "riot" that shook Cincinnatians' faith in their city's republican government and rule of law. Energized by the Nuncio's arrival, activists assembled at Freemen's Hall on Christmas morning to coordinate resistance against the "Butcher of Bologna." Despite the Hochwächter's chilling rhetoric and the New York Italians' precedent, however, the Freemen planned a "pacific demonstration" and effigy burning. ${ }^{103}$ But as the Freemen built mock gallows, city officials prepared for war. In the eyes of Democratic Mayor David Snelbaker, the Freemen intended to

\footnotetext{
${ }^{98}$ Levine, Spirit of 1848, 46-48, 53, 186; Daily Enquirer, December 25, 1853.

${ }^{99}$ Daily Enquirer, December 27, 1853.

${ }^{100}$ Ibid., December 29, 1853.

${ }^{101}$ Honeck, We Are the Revolutionists, 22-23.

${ }^{102}$ Hochwächter quoted in Mairose, "Nativism on the Ohio," 72. No original copies of the paper remain.

${ }^{103}$ Daily Enquirer, December 29, 1853.
} 
disturb the civic peace and violate the republican principle of extending hospitality to foreign visitors such as Bedini. Unaware of these police preparations, hundreds of men and women departed Freemen's Hall around ten o'clock in the evening, passing merrymakers and gathering new recruits on the way. ${ }^{104}$ Then, not far from the rectory where Bedini was sleeping, police officers suddenly appeared. ${ }^{105}$ To the Freemen, it was an ambush; to the officers, a defense of law and order. The officers never read the riot act and instead launched into the protestors, turning the standoff into a melee. Within five or ten minutes, the skirmish was over. Surprised and overpowered, the Freemen beat a hasty retreat, leaving young immigrant Karl Eggerlin mortally wounded and sixty-three other marchers in custody. ${ }^{106}$ The Freemen's Plum Street "protest" was finished, but their fight to define the limits of democracy had just begun.

These conflicting descriptions of the "Bedini Affair," as the Christmas disturbance and its related partisan recriminations came to be known, shed light on antebellum Cincinnati's turbulent and transatlantic political culture. City officials, faithful Catholics, German Freemen, and native-born residents all fashioned self-serving narratives that provided different accounts of, and ascribed different meanings to, this holiday "protest," "riot," and "Affair." Through newspaper editorials, legal trials, mass meetings, and effigy burnings, these groups wrestled with contrasting views of democracy, citizenship, republican virtue, civic freedom, and American exceptionalism. Indeed, their fights often featured opposing definitions of the same terms: Catholics viewed obedience as the path to freedom, while Freemen conceived of freedom as the absence of obedience. Native-born citizens similarly rushed to the Freemen's defense by casting

${ }^{104}$ Levine, Spirit of 1848, 188-191; Mairose, "Nativism on the Ohio," 72-76; Honeck, We Are the Revolutionists, 76; Connelly, Visit of Archbishop Gaetano Bedini, 97-103; Daily Enquirer, December 27, 1853; December 29, 1853.

${ }_{105}$ Daily Enquirer, January 6, 1854; Gazette, December 31, 1853.

${ }^{106}$ Levine, Spirit of 1848, 190; Daily Enquirer, December 27, 1853; December 29, 1853; Gazette, December 26, 1853. 
themselves as defenders of liberty even as the Germans called American exceptionalism's bluff. In the Christmas conflict's aftermath, local concerns over education, street preaching, and corruption mixed with European revolutionary grudges and debates about universal values to produce a contentious political environment.

These opposing voices also revealed antebellum Cincinnati's fluid partisan alliances. As American socialism foundered in the wake of 1848, Ohio Whigs became unable to provide local voters with a compelling alternative to Democratic law and order. Instead, Cincinnati nativists and freethinking émigrés believed that the 1853 Whig mayoral campaign platform mirrored Snelbaker's Democratic embrace of immigrants and Catholics. The Whigs' party infrastructure, already weakened by their disastrous 1852 presidential campaign, collapsed as former allies turned to third-party candidates. ${ }^{107}$ With the Whigs in freefall, traditional party loyalties and ethnic and sectional divides were temporarily suspended as frustrated Cincinnatians searched for ways to confront Democratic rule. Governmental reform and sectarianism served as the rallying cries for this new multiethnic movement. ${ }^{108}$ As Ohio historian Mary Alice Mairose noted, "rather than reflecting a real fusion of conflicting elements concerned with national issues, the independent party addressed more immediate local issues and longstanding prejudices against Catholicism." ${ }^{\prime 109}$ These instances of interethnic cooperation later faded from view as partisan lines re-solidified and Know Nothings, Republicans, and Democrats jockeyed for electoral position. By 1855, in fact, Cincinnati nativists and Germans were fighting each other in the streets over alleged voting fraud. ${ }^{110}$ Yet the Bedini Affair illustrated that the Whigs' final

\footnotetext{
${ }^{107}$ Michael Holt, The Political Crisis of the 1850s (New York: W.W. Norton, 1983), 109-136; Mairose, "Nativism on the Ohio," 45-49.

${ }^{108}$ Most scholars have emphasized anti-slavery views as the reform movement's uniting force. See Anbinder, Nativism and Slavery, 97-102; Honeck, We Are the Revolutionists, 5-34, 71-103.

${ }^{109}$ Mairose, "Nativism on the Ohio," 107.

${ }^{110}$ Grimsted, American Mobbing, 228-229.
} 
collapse and the Know Nothings' meteoric rise were far from foregone conclusions in January 1854. Instead, this chapter emphasizes the contingent nature of American political history and points to the shared belief in natural rights liberalism that united Whigs, avowed nativists, and Freemen after the "riot." Within a decade, liberal ideals would lead many of these voters into the emerging Republican coalition. ${ }^{111}$

Months before Bedini's arrival, Cincinnati’s latest school funding controversy exposed the city's political fluidity and anti-Catholic leanings. While German Freemen and native-born Protestants disagreed over the exact definition of democracy, they shared the belief that public schools should inculcate students with a love for liberty. Yet the city's preferred republican and nonsectarian curriculum offended local Catholics, who argued that their tax dollars were being spent on schools that disparaged their faith. In response, they suggested that tax revenues should also fund parochial schools. Protestants and German freethinkers were outraged by this proposal, which they portrayed as a Catholic takeover of education that would doom future generations to irrationality and tyranny. ${ }^{112}$ All of the city's mayoral candidates, including Snelbaker, reacted by casting themselves as critics of Catholicism. Third-party candidates split the spring election field and ensured Snelbaker's victory, but many of his opponents remained convinced that campaign rhetoric aside, their new Democratic mayor took his orders from Archbishop Purcell, not the people. $^{113}$

Snelbaker was barely settled into office when an itinerant firebrand cast the city into another fight over religious liberty and democratic rights. In April, street preacher Hugh

\footnotetext{
${ }^{111}$ Anbinder, Nativism and Slavery, 247-261; Holt, Political Crisis, 180; Honeck, We Are the Revolutionists, 71-79.

${ }^{112}$ McGreevy, Catholicism and American Freedom, 19-38; Rev. John H. Lamott, S.T.D., History of the Archdiocese of Cincinnati, 1821-1921 (Cincinnati: Frederick Pustet Company, 1921), 279; Walter Glazer, Cincinnati in 1840 (Columbus: The Ohio State University Press, 1999), 36.

${ }^{113}$ Grimsted, American Mobbing, 228.
} 
Kirkland visited the downtown market and launched into an anti-Catholic diatribe inspired by popular accounts of nunnery debaucheries. Catholics and Protestants were soon fighting in the streets, and residents feared that the preacher would provoke an all-out riot. ${ }^{114}$ Ironically, in past decades Cincinnatians would have accepted, if not welcomed, a violent settlement to the dispute: between 1788 and 1848, the city experienced eleven major mob outbreaks over abolitionism, immigration, and other socioeconomic concerns. City elites viewed these demonstrations as relatively painless ways for plebeians to vent their frustrations without jeopardizing governmental institutions, while rioters believed that their actions checked tyranny and rejuvenated the city's republican character. ${ }^{115}$ As one Ohio historian argued, "mobocracy" was seen as "the ideal of government."116 By the mid-1840s, however, city elites were concerned by the physical brutality and property damage associated with urban rioting. Mob demonstrations were no longer seen as frivolous carnivals that symbolically protected the republic. Instead, elites worried that the increased violence presaged a breakdown in civil society and a dangerous turn toward European radicalism. ${ }^{117}$ Because the rule of law protected constitutional rights in the United States, elites argued, mob actions were unnecessary. ${ }^{118}$ Snelbaker shared these views and sought to stave off another riot by personally issuing a cease and desist request against Kirkland. Yet the Mayor's decisiveness backfired because native-born voters - many of whom had disapproved of the preacher's words and actions - interpreted this police action as an attack on free speech. ${ }^{119}$ Residents demanded Snelbaker's resignation, a citizens' committee blamed his

\footnotetext{
${ }^{114}$ Grimsted, American Mobbing, 228; Mairose, "Nativism on the Ohio," 50.

${ }^{115}$ Gilje, Road to Mobocracy, 5-30; Patrick Folk, "“The Queen City of Mobs': Riots and Community Reactions in Cincinnati, 1788-1848" (Ph.D. dissertation, University of Toledo, 1978), 1-3.

${ }^{116}$ Charles Goss quoted in Folk, "Riots and Community Reactions," 1.

${ }^{117}$ Gilje, Road to Mobocracy, 135, 205; Folk, "Riots and Community Reactions," 354-361; Smith, The Dominion of Voice, 23-40.

${ }_{118}$ Smith, The Dominion of Voice, 40-52.

${ }^{119}$ Folk, "Riots and Community Reactions," 336-359; Mairose, "Nativism on the Ohio," 50; Glazer, Cincinnati, 73-77.
} 
election on voter fraud, and some enraged citizens threatened to kill any officer who tried to silence Kirkland. $^{120}$

Reports of police favoritism further incensed Snelbaker's critics and resurrected claims that the Mayor sympathized with Catholics. On the same day Snelbaker silenced Kirkland, voters later learned, seventeen police officers had guarded a Church procession. Non-Catholics flocked to a public meeting at which speakers railed indignantly against the Mayor's intolerance and injustice. Archbishop Purcell and his followers were allowed to violate the Sabbath with impunity, they complained, while Catholicism's critics were abused and oppressed. ${ }^{121}$ These charges resonated on both political and emotional levels for many Cincinnatians, who were anxious about their clannish Catholic neighbors. Under Purcell's leadership, the city's small faith community had grown into one of the most powerful Catholic organizations in the country, complete with its own aid societies and newspaper. ${ }^{122}$ To many Protestants, the Archbishop's biography read as a long train of abuses: after a series of contentious theological debates with clergyman Alexander Campbell in 1837, he successfully persuaded the city's school board to exempt Catholic students from reading the King James Bible in $1842 .{ }^{123}$ Conspiracy tales grew with each provocation, causing lecturers to debate the Church's stance on republicanism and nativists to repeat local clergyman Lyman Beecher's prophecy that Catholic immigrants were a "train of powder between the enemy's camp and our own magazine, which, once ignited, would destroy the American republic." ${ }^{124}$ Eventually, Snelbaker relaxed his guard and allowed the itinerant preacher to appear in public once more. Yet many Whigs and nativists remained

\footnotetext{
${ }^{120}$ Mairose, "Nativism on the Ohio," 50-54.

121 Ibid., 51-55.

${ }^{122}$ Levine, Spirit of $1848,95$.

${ }^{123}$ McCann, "Purcell," 177; Mairose, "Nativism on the Ohio," 46.

${ }^{124}$ Lyman Beecher quoted in Le Beau, "Anti-Catholic Propaganda," 106. See also the Daily Enquirer,
} November 24, 1853; December 8, 1853. 
convinced that their constitutional rights were being endangered by widespread Catholic influence and Democratic corruption. To these residents, Snelbaker's heavy-handed tactics revealed his inability, or unwillingness, to differentiate between lawful free speech and mob violence. $^{125}$

Voters also turned a wary eye towards the city's German socialists, who appeared poised to replace democracy with Continental terror even as Snelbaker threatened to inaugurate an era of tyranny. German immigrants had long played an active role in Cincinnati society as laborers and intellectuals, but by 1853 the city's Over-the-Rhine neighborhood was a fractured and heterogeneous community. ${ }^{126}$ German Protestants adhered to their churches' political and theological orthodoxy, while Catholics remained loyal to the Holy See and supported their own parochial aid societies. In sharp contrast, political exiles constructed a new civil society to support their secular and egalitarian ambitions. Cincinnati Germans founded the nation's first Turnverein society for gymnastics and free discussion, while Workingmen's Club members fought for union rights and the Freemen organized public lectures, mass meetings, and theatre performances. ${ }^{127}$ Most native-born Cincinnati residents were horrified by these developments and the immigrants' growing political clout. In the months leading up to Bedini's visit, nativists chided Germans for taking an active role in the city's Independence Day celebrations, immigrants were implicated in several publicized street fights, and native-born residents ridiculed the Freemen's published party platform and dramatic effigy burning of an suspected Prussian spy. ${ }^{128}$ In the words of British visitor Isabella Bird, these "skilled, educated, and

\footnotetext{
${ }^{125}$ Mairose, "Nativism on the Ohio," 55.

${ }^{126}$ Honeck, We Are the Revolutionists, 74.

${ }^{127}$ Honeck, We Are the Revolutionists, 21-23, 72-75; Levine, Spirit of 1848, 91-99.

${ }^{128}$ Mairose, "Nativism on the Ohio," 58-60.
} 
intellectual" exiles were "an influence of which the Americans themselves are afraid." ${ }^{129}$ Fear and uncertainty pervaded Cincinnati political culture on the eve of Bedini's visit. Concerns over the future viability of American constitutional democracy animated native-born residents, Whigs struggled to resist Snelbaker and revive their dying party, and German émigrés sought to reform civil society and government. Like a spark to dry kindling, the Nuncio's arrival ignited these debates into a raging firestorm of democratic resistance and dissent.

Growing public opposition to mob violence and continued fears over the future of American democracy shaped early newspaper accounts of the Germans" "Sunday Night Affair," which portrayed police officers as heroes who had shielded citizens from foreign secularism and socialism. Even the Daily Cincinnati Gazette, an old Whig organ with no love lost for Snelbaker, opened its coverage of the Christmas "breach of the peace" by reminding readers of the Freemen's longstanding opposition to organized religion, their recent effigy burning of the supposed spy Junghaus, and their continued devotion to "what they call liberty." "130 This love of “so-called" liberty, the paper's Whig editor explained, merely masked the violent and uncompromising nature of mob actions. Police reports revealed that almost every Freeman arrested in the streets had been armed, just as the Hochwächter's incendiary comparisons between Bedini and Austrian counterrevolutionary Ludwig Haynau - who barely survived the 1850 attack on his life by brewers in London - suggested that the Germans had planned more than an effigy burning against Bedini. ${ }^{131}$ Yet whether the Freemen were armed to kill or merely prepared to defend themselves was ultimately irrelevant, the Democratic Daily Enquirer argued, because the foreigners' organized presence on the streets had needlessly shaken proper city

${ }^{129}$ Isabella Bird quoted in Honeck, We Are the Revolutionists, 75-76.

${ }^{130}$ Gazette, December 26, 1853.

131 Daily Enquirer, December 27, 1853; Margot Finn, “'A Vent Which Has Conveyed Our Principles:' English Radical Patriotism in the Aftermath of 1848," The Journal of Modern History 64 (1992): 644-645. 
society. As the paper's devout writers noted, the United States was founded on Christian, not secular, principles - and thus the Christmas "rioters" posed a shocking and impermissible provocation to American sensibilities and the rule of law. ${ }^{132}$

In light of this blatant breach of the holiday peace, the Enquirer continued, city watchmen were left with no choice but to rein in the lawless Germans. On Christmas, Snelbaker and Police Chief Thomas Lukens had received intelligence confirming the Freemen's planned attack on Purcell's residence. With no time to lose, Lukens and Police Judge William Spooner were soon on the scene readying their men for the onslaught. A little after ten o'clock, the Freemen finally appeared. Marching four abreast with captains at the head of each division - as if to confirm Snelbaker's worst fears about German paramilitarism - the socialists defiantly made their way toward the waiting policemen. ${ }^{133}$ Within minutes, the officers made dozens of arrests and restored calm to the streets. "In checking and quelling such disorderly outbreaks," Democratic writers argued, these forceful actions were "commendable in every sense of the word."134 The Freemen rejected Snelbaker's narrative, arguing that the police had carried out a brutal and unprovoked attack on peaceful protestors, editors noted, but the Germans' secrecy, rhetoric, and defiance betrayed their true intentions. After years of turmoil and controversy, officials in Cincinnati, the "Queen City of Mobs," finally seemed willing to protect life, property, and civic peace by acting decisively against lawless demonstrators. ${ }^{135}$

While the Gazette promoted similar views of restrained, peaceful republicanism, its initial partisan skepticism of police violence and city leadership foreshadowed changing views of

\footnotetext{
${ }^{132}$ Daily Enquirer, December 27, 1853. During this time period, the Enquirer's Sunday editions all featured lengthy religious devotionals and reflections.

${ }^{133}$ On December 26 the Gazette suggested the Freemen numbered between 1,000 and 1,200, while the next day the Enquirer lowered the estimate to between 800 and 1,000.

${ }^{134}$ Daily Enquirer, December 27, 1853.

135 Ibid.
} 
the Christmas "riot." Unlike their Democratic competitors, who largely narrated the street clash from Lukens's perspective, Whig writers placed the conflict into a broader transatlantic context by repeating Gavazzi's charges against Bedini in painstaking detail. The Gazette made no effort to substantiate these claims, but the insinuation was clear: if true, descriptions of Bassi being skinned and flayed alive on the Archbishop's personal orders certainly justified the Freemen's anger. ${ }^{136}$ Other discrepancies in the official police report attracted the Whigs' attention: just months before, they remembered, the Freemen had burned Junghaus' effigy and "though there was some harm there was then no confusion." ${ }^{137}$ Why had the Christmas disturbance escalated into chaos? Because the watchmen appeared to have taken the initiative, was this "riot" actually a case of police overreach? These crucial questions, the Gazette concluded, could only be answered at the Germans' upcoming court examination. Although wary of the marchers' radicalism, the writers also remembered Snelbaker's bungled response to the Kirkland Affair. After all, Whigs argued, evidence of the Freemen's murderous intent had probably been "colored and distorted." 138 These writers were outraged by any disturbance of the Sabbath, but they remained unwilling to lay full blame for the violence at the feet of the Freemen. Instead, the Whigs' partisan agenda encouraged them to support the rights of foreigners against autocratic Democrats.

The Freemen seized upon these tentative signs of support to promote their own accounts of police brutality and illiberal government. Within hours of their silenced "protest," the Freimänner were already in the streets, handing out circulars and posting signs that explained their hatred of Bedini. These talking points were summarized in their December 28 Address, which appeared in the city's leading newspapers just one day before the marchers' court case

\footnotetext{
${ }^{136}$ Gazette, December 26, 1853.

${ }^{137}$ Ibid.

${ }^{138}$ Ibid.
} 
began. ${ }^{139}$ In this succinct, idealistic, and yet pragmatic document, the Freemen described the Christmas disturbance as an unlawful attack that transcended local bickering over Snelbaker's competence to reflect the nation's disturbing turn against democratic demonstrations. In the Germans' account, the Christmas marchers merely intended to "read aloud . . of this Bedini, his murders and actions, and then quietly retire." ${ }^{140}$ The Enquirer's description of the loud, intimidating, and trigger-happy crowd confronting Lukens was wildly inaccurate, the Freemen argued, since women and curious citizens had joined in the friendly excitement. Yet with a cry of "pitch in!" city policemen suddenly ambushed the crowd without regard for basic civic protocol. "No word of persuasion," the Freemen bitterly complained, "was used towards us." On Christmas, only batons and guns spoke, leaving several of the Freemen badly beaten and imprisoned in the watch-house. For decades, native-born apologists for national exceptionalism had presented the American Revolution as a relatively bloodless war that produced a shining example of good governance. ${ }^{141}$ Yet here was evidence not of national greatness, but of hypocrisy and degeneration from democratic ideals. Unprovoked police attacks were expected in papal Rome, not republican Cincinnati.

Conscious of Cincinnati's long-standing anti-Rome biases, the Freemen linked Catholicism with arbitrary legal rulings and undemocratic justice. Through the storms of economic depression, war, and sectionalism, antebellum Americans clung to their faith in constitutional structures that preserved order and maintained fairness and impartiality. Just months before the Christmas disturbance, President Franklin Pierce had even urged Americans to

\footnotetext{
${ }^{139}$ Levine, Spirit of 1848, 188-192; Daily Enquirer, December 29, 1853.

${ }^{140}$ All quotes from the Address are taken from the Daily Enquirer, December 29, 1853.

${ }^{141}$ Roberts, Distant Revolutions, 4-16.
} 
renounce political agitation and place their trust in the impartial rule of law. ${ }^{142}$ Yet in the eyes of both German exiles and loyal nativists, Catholic laymen undermined American law and order by pledging their primary allegiances to the Vatican rather than the Constitution. In Europe, Catholicism reinforced authoritarianism; in America, Catholics could swing elections by voting en masse for their bishops' favored candidates. ${ }^{143}$ In an ironic twist, the Freemen employed the familiar claims of leading American nativists to show how equality under the law evaporated in the presence of Catholicism's hierarchical despotism. Even in Cincinnati, once home to Beecher and other prominent anti-Catholic leaders, the Pope's degenerative influence still achieved disastrous effects. Desperate for Catholic approval and votes, Snelbaker had turned against basic fairness. Fickle fans of free speech and equality, American leaders such as Snelbaker were no better than European dictators. "If we live under the control and government of Jesuits," the Freemen cried, "we want also to know it."

These frequent references to European tyranny underscored the universal implications of natural rights liberalism. As heirs to the Enlightenment's democratic tradition, the Freemen argued that all men deserved free government and civil liberty. Inspired by their European memories and American experiences, exiles eschewed national boundaries and sought to protect civil rights wherever they were endangered. ${ }^{144}$ In this view, a theocratic enemy of Bologna was also an enemy of Cincinnati, while constant vigilance and effort were needed to democratize Europe, improve the United States, and prevent republics from backsliding into authoritarianism. Significantly, the first lines of the Address referenced Europe rather than Cincinnati: "the arrival in town of the Pope's Nuncio . . brought among us painful recollections," the Freemen declared,

\footnotetext{
${ }^{142}$ President Franklin Pierce, Inaugural Address, March 4, 1853, Franklin Pierce Papers, Library of Congress (Washington, DC).

${ }_{143}$ Anbinder, Nativism and Slavery, 110-126.

${ }^{144}$ Levine, Spirit of 1848, 41-46; Honeck, We Are the Revolutionists, 2-8; Körner, ed., 1848, 3-16.
} 
for "the name of Bedini called to our mind the tyrannical death of Ugo Bassi." Of course, not a single Freeman was actually in Bologna, let alone Italy, during Bedini’s alleged crimes. And ironically, the Nuncio's earlier work on behalf of immigrants living in Brazil earned him the enduring respect of that nation's struggling German population. ${ }^{145}$ But these Freemen were global democratic citizens, not narrow-minded nationalists, and they viewed resistance to the tyrannical Bedini not only as a cherished civil right, but as their solemn duty.

These cosmopolitan ideals led German exiles to embrace the rights and responsibilities of American citizenship. Their rhetoric, in fact, struck a remarkably conciliatory tone with nativeborn voters: unlike the Society's earlier party platform, which maintained vestiges of European socialism, the Address incorporated the language and values of the Founding Fathers. ${ }^{146}$ America served not only as the Germans' refuge but as their "adopted country," a sanctuary of liberty where life was lived "under the protection of . . f free institutions." With bitter 1848 experiences still fresh in their minds, the Freemen appreciated the courage and sacrifice once displayed by the American Revolution's patriots. These heroes provided antebellum Americans with a priceless national heirloom: a set of republican principles and a system of limited government in which all citizens were free to live their lives under the impartial rule of law. Yet this republic was not self-perpetuating; for good or ill, government reflected the will of the people - and thus corruption, ignorance, and other unchecked vices could ultimately trigger its collapse. To ensure its survival, every resident was obliged, in the Freemen's words, "to observe and support to [their] last drop of blood the constitution" of the United States. Like Adams and Washington before them, the Freemen saw freedom not only as a universal right, but also as the ability to

\footnotetext{
${ }^{145}$ Connelly, Visit of Archbishop Gaetano Bedini, 289.

${ }^{146}$ Mairose, "Nativism on the Ohio," 60.
} 
exercise human agency and resist tyranny. ${ }^{147}$ Once again, the Germans' rhetoric echoed the claims of nativists who saw threats against American freedoms lurking around every corner. Yet beneath the Freemen's love of liberty also lay a forceful defense of immigrant voting rights. American citizenship, they argued, did not demand lengthy lectures about electoral politics or an apprenticeship in liberty, but rather a willingness to become a martyr for freedom. ${ }^{148} \mathrm{~A}$ republican citizen could maintain multiple loyalties so long as all of these efforts supported liberty, and thus the Freemen saw no contradiction between their American citizenship and cosmopolitan identities.

Despite their strong identification with American ideals, the Freemen's embrace of universal values ultimately produced a strong critique of national exceptionalism. In the Address, explicit references to constitutionalism and citizenship were subtly clarified and critiqued to illustrate the growing divide between democratic theory and democracy's practice in the United States. The Freemen seemed uneasy labeling themselves as full citizens and instead mixed references to famed foreign refugee Martin Koszta and "the common ties of brotherhood" with discussions of their American identities. This apparent contradiction stemmed from the Germans' forward-looking and reform-minded view of citizenship and democracy. In the Freemen's view, the Founding Fathers had begun to construct an inspiring democratic state. But after this promising start, the nation devolved into a petty republic: the Constitution's highest ideals, still unfulfilled at the Founders' passing, were corrupted by antebellum power and greed to reflect restrictive views of popular government. As one German newspaper argued, the United States was "The Land of Contradictions" where professed lovers of liberty still limited suffrage,

\footnotetext{
${ }^{147}$ Francois Furstenberg, "Beyond Freedom and Slavery: Autonomy, Virtue, and Resistance in Early American Political Discourse," The Journal of American History 89 (2003): 1296-1297.

${ }^{148}$ Anbinder, Nativism and Slavery, 119-126.
} 
enslaved innocent blacks, and crushed any form of organized dissent. ${ }^{149}$ These abuses horrified the Freemen, who disavowed current national conditions and redoubled their efforts to remake the United States into a haven of freedom. Democratic prophets in a foreign land, they aimed to cajole, inspire, and provoke native-born Americans to seize their nation's boundless potential. As news of the Christmas disturbance spread, exceptionalist ideology became a rhetorical weapon for the Freemen, who sought to contrast their treatment in the streets of Cincinnati with the Constitution's free speech provisions. Here, the Germans cried, was a chance for citizens to reverse their democracy's downward trend. As the Address concluded, "we . . . call upon the American citizens to take our case in consideration, from whom we expect that vindication which is due to our character."

The Freemen were ironically vindicated by their police attackers, whose descriptions of street violence and jailhouse brutality undermined the city's own prosecutors. After days of tension and controversy, dozens of German defendants squeezed into an overfilled courtroom on December 30 to begin their hearing in front of Judge William Spooner, the same magistrate who accompanied Lukens on Christmas. Not surprisingly, the Democratic Police Chief appeared as the prosecution's first witness, furnishing evidence of the Germans' "intent to do an unlawful act, with force and violence, against the person of one [Gaetano] Bedini." ${ }^{, 150}$ At first, the inexperienced Lukens - who had been on the job for only two weeks - stuck to his script, detailing the Freemen's defiant and threatening attitude, the piercing sound of the first unordered gunshot, and the police's steady and methodical efforts to break up the march. ${ }^{151}$ But as the Chief and his officers continued, a new and disturbing portrait of the "riot" came into view. Lukens

\footnotetext{
149 Sociale Republik quoted in Levine, Spirit of $1848,89$.

${ }^{150}$ Daily Enquirer, December 31, 1853.

${ }^{151}$ Summaries of the December 30 court testimony were published in the December 31 editions of both the Daily Enquirer and Gazette.
} 
admitted to kicking three men and observing prisoners being roughly shoved into the watchhouse; Officer Thomas Meara remembered seeing men "so crowded they could not sit down in" the jail cells; another watchman recounted how peers aggressively yelled "pitch in!" as they plunged into the Germans. Father Edward Purcell, the Archbishop's brother, cast further doubts on the prosecution's narrative by admitting that Bedini slept through the entire ordeal. ${ }^{152}$ After a short recess, the court reconvened to find that the prosecution, having "failed to make out a case," now planned to dismiss all charges. ${ }^{153}$

These stunning courtroom developments forced Snelbaker to recast the Christmas arrests as a noble fight for civic virtue. The Mayor made no effort to dodge allegations of police brutality but rather spread blame for the violence, highlighting the Germans' socialist history and the importance of national hospitality. "No man deplores the unhappy occurrences of that night [Christmas] more than myself," Snelbaker argued, but "several persons, well known to the community ... [also] mingled in the melee and used great violence."154 This conspiratorial tale challenged courtroom depictions of an orderly "protest" even as it rebuked the city's prosecutor for emphasizing violence at the expense of the Freemen's murderous intentions. As Snelbaker reminded city councilmen, the Germans had violated the limits of acceptable free speech by printing libelous accounts aimed at inciting physical violence against Bedini. Yet now the Freemen hypocritically claimed innocence because Bedini escaped unscathed, even though only decisive police action had saved the Nuncio from harm. The Germans' dramatic appeals to the memory of Martin Koszta were similarly unfounded, since Snelbaker's republican hospitality mirrored the U.S. Navy's earlier protection of the famous Hungarian refugee. "The same people who threw the shield of the Republic over Koszta" in Turkey, the Mayor insisted, must "also

\footnotetext{
152 The policemen's descriptions and quotes are taken from the Daily Enquirer, December 31, 1853.

${ }_{153}$ Daily Enquirer, December 31, 1853. See also Levine, Spirit of 1848, 190.

${ }^{154}$ Daily Enquirer, January 5, 1854.
} 
protect Koszta at home, or Bedini, or any other man sojourning among them." ${ }^{\text {155 }}$ Members of the Cincinnati police initiated excessive violence on Christmas, Snelbaker admitted, and he would follow standard city protocol to punish the offenders. But he also asked constituents to look beyond this immediate street violence and toward the larger forces that threatened Cincinnati. Through their words and actions, the Freemen had manipulated their listeners - in reality, their socialist views endorsed unfettered speech and unlimited violence. In Snelbaker's view, these radical beliefs posed a dangerous threat to the institutional stability, mutual respect, Christian charity, and traditional deference that defined American republicanism. ${ }^{156}$

Snelbaker's Whig and nativist critics were unimpressed by this defense, which they interpreted as a self-serving report calculated to protect the Mayor's reputation rather than republicanism. Local Whig attorney William Dickson, who just a week before had prosecuted the Freemen, now made the most public case for Snelbaker's dishonesty and negligence. ${ }^{157}$ Despite the Democratic Mayor's claims, Dickson argued in his January 6 editorial, no evidence showed that the Freemen had planned anything more than a protest. Even the infamous Hochwächter rants against Bedini were mere rhetorical flourishes, he continued, and witnesses had made no references to planned violence. Shockingly, the prosecutor claimed that the Mayor himself was fully aware of the Germans' innocence, for "he repeatedly and earnestly importuned me on the days between the arrest and the trial, to dismiss the charge of Riot, the charge of an intent to assassinate Bedini, and prefer the charge of Disorderly Conduct, on the ground that the former charge could not be sustained." ${ }^{\prime 58}$ Faced with evidence that his preemptive policies and overly narrow views of free speech had produced catastrophe, Snelbaker should have admitted

155 Daily Enquirer, January 5, 1854; Encyclopedia Americana, 1920, s.v. "Koszta Affair."

${ }^{156}$ Daily Enquirer, January 5, 1854; Levine, Spirit of 1848, 190.

${ }^{157}$ Mairose, "Nativism on the Ohio," 85-87; William Dickson Papers, Biographical Introduction, William L. Clements Library Manuscripts Division, University of Michigan (Ann Arbor, Mich.).

${ }^{158}$ Gazette, January 6, 1854. Emphasis original. 
his mistake and allowed the justice system to discipline Lukens and the watchmen. Instead, the Mayor became an autocrat, concealing official evidence and agitating for false imprisonments. As Dickson lamented, "never before has there been such an array of official pressure to hurry a conviction against law and evidence." ${ }^{159}$ Officials such as Snelbaker, who trampled civil liberties and tried to warp the law to suit their own ends, were the true enemies of American freedom. As the partisan Gazette concluded, nothing was "too mean to expect of a man who sets in motion the murderous machinery used on Sunday night, and then skulks away to enjoy a merry Christmas with his friends."160

With public outrage at a fever pitch, Kirkland's old supporters reassembled to support political liberalism and voice their disapproval of Snelbaker's latest crackdown. ${ }^{161}$ Once again, speakers rose to chastise the Mayor while a large and boisterous crowd responded with loud cheers and chants of "Down with the Pope!", 162 Resolutions against Judge Spooner, Lukens, and the watchmen were quickly approved, as were measures reaffirming the public's right to defend liberty and peacefully assemble in protest. Importantly, these messages employed the language of natural rights liberalism to define freedom as the exercise of human agency, while speakers repeatedly emphasized the similarities between American freemen and German Freemen. Both groups stood ready to resist threats to liberty and viewed public education as an unassailable right, even as their efforts were constantly contested by "Snelbaker and his friend Bishop Purcell." ${ }^{\prime 163}$ Native-born speakers reminded their listeners of Snelbaker's rumored support for parochial schools and his attempts to silence Kirkland, while the Freemen's spokesman dwelt at length upon Bedini's alleged scalping of Ugo Bassi. These conspiratorial tales worked the crowd

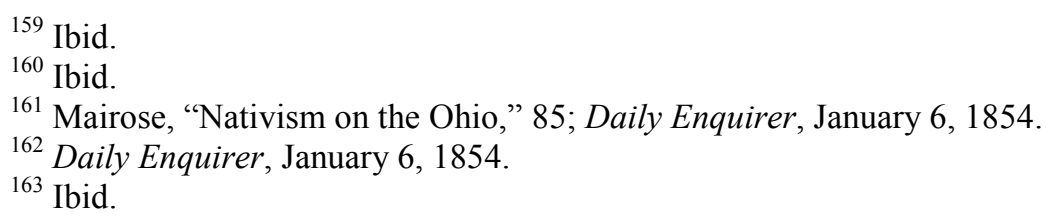


into a spirited frenzy, and soon participants were loudly calling for Bedini's effigy to be burned. In this singular moment, Cincinnati's three main anti-Democratic groups appeared united by their shared hatred of Snelbaker and distrust of Catholicism. Whigs sought to re-energize their sagging electoral base by accusing the Mayor of incompetence and tyranny, while more dedicated nativists zeroed in on Snelbaker's rumored links to the city’s powerful Archbishop. Meanwhile, German freethinkers discussed the broader shortcomings of American democracy. Despite the Freemen's socialist past, their spirited physical defense of civil rights and rhetorical shift towards American liberalism impressed their native-born neighbors, who now saw them as convenient allies in the fight against Democratic arrogance and corruption. ${ }^{164}$

In contrast, Cincinnati Catholics privately viewed these conflicts as failed attacks on the Nuncio and the Church. At Bedini's request, a procession to celebrate the dedication of Holy Trinity Church was quietly cancelled, while few laymen played noticeable roles in the Freemen's court proceedings. ${ }^{165}$ As Pennsylvania Bishop Michael O’Connor counseled Purcell, provocative statements only encouraged the Church's enemies, but continued stoicism would expose the Freemen's radicalism and prevent attempts to revive anti-Bedini sentiment in other cities. ${ }^{166}$ Even so, prelates broke their silence when presented with meaningful opportunities for dialogue and reconciliation. On December 29, Bedini met with a freethinking German newspaper editor to discuss civil liberty, while two days later Purcell sent ten dollars to support the Freemen's fundraising campaign for wounded rioters. ${ }^{167}$ "When there is a question of relieving those who suffer and are poor," the Cincinnati Archbishop noted, "all differences of faith and opinion

\footnotetext{
164 Ibid.

165 Mairose, "Nativism on the Ohio," 76, 94; Daily Enquirer, December 30, 1853; December 31, 1853.

${ }^{166}$ Bishop Michael O'Connor, letter to Archbishop John Purcell, December 29, 1853, Archdiocesan Records, Electronic Archival Calendar, University of Notre Dame Archives (Notre Dame, Ind.).

${ }^{167}$ Archbishop John Purcell, letter to Archbishop Anthony Blanc, December 30, 1853, Archdiocesan Records, Electronic Archival Calendar, University of Notre Dame Archives (Notre Dame, Ind.).
} 
should be forgotten." ${ }^{168}$ Yet neither effort succeeded in de-politicizing Cincinnati's increasingly hostile and fractured society. Purcell praised the Nuncio's dignified and gentle bearing, but the Freemen only increased their attacks on Bedini's character. ${ }^{169}$ The Germans also angrily returned Purcell's donation, which they viewed as the tainted funds of a tyrant: "a Jesuit under the guidance of the despotic King of Rome can never mean good, nor deal with sincerity toward men known to cherish republican opinions." ${ }^{170}$ Infuriated by this reply, Father Edward Purcell responded with a scathing editorial of his own that accused the Germans of corrupting their countrymen. ${ }^{171}$ Yet his brother, the Archbishop, refused to escalate the fight and instead praised the reserve and dignity of Cincinnati Catholics. Old religious, ethnic, and political divisions within the Church were now forgotten, Purcell noted, for the "riot" had increased the fervor of many previously lukewarm laymen. ${ }^{172}$ In the world's eyes, the Archbishop had lost; in his eyes, he had won souls for Christ.

For Catholic leaders, the Bedini Affair presented a theological test rather than an extended democratic debate. In light of ultramontane theology, Purcell and Bedini interpreted the Christmas Riot as a religious event: weighed down by sin, the "infidel" Freemen had lashed out against the Nuncio, a visible reminder of the Church's power and moral certitude. ${ }^{173}$ In their private correspondence, the prelates embraced visions of the suffering Christ and linked their

${ }^{168}$ Daily Enquirer, January 3, 1854.

${ }^{169}$ Archbishop John Purcell, letter to Archbishop Anthony Blanc, December 30, 1853, Archdiocesan Records, Electronic Archival Calendar, University of Notre Dame Archives (Notre Dame, Ind.).

${ }^{170}$ Daily Enquirer, January 3, 1854.

${ }^{171}$ Mairose, "Nativism on the Ohio," 74-75.

172 Mairose, "Nativism on the Ohio," 91-95; Archbishop John Purcell, letter to Archbishop Anthony Blanc, January 21, 1854, Archdiocesan Records, Electronic Archival Calendar, University of Notre Dame Archives (Notre Dame, Ind.).

${ }^{173}$ Archbishop John Purcell, letter to Archbishop Anthony Blanc, December 30, 1853, Archdiocesan Records, Electronic Archival Calendar, University of Notre Dame Archives (Notre Dame, Ind.); Archbishop Gaetano Bedini, letter to Archbishop John Purcell, January 2, 1854, Archdiocesan Records, Electronic Archival Calendar, University of Notre Dame Archives (Notre Dame, Ind.); Archbishop John Hughes, letter to Archbishop Anthony Blanc, January 2, 1854, Archbishop John Hughes Papers, American Catholic History Research Center and University Archives, Catholic University of America (Washington, DC). 
own struggles and abandonment to the sacrifice of the Cross. Purcell preferred to see Bedini back safe in Rome, he admitted, but until then he would selflessly stand alongside him, prepared at any moment to protect his friend from assassination. ${ }^{174}$ Despite his own private fears, Bedini also continued to tour the city's Catholic institutions and churches after Christmas, later writing to Purcell that he rejoiced in being found worthy to suffer. ${ }^{175}$ In this letter, which was soon reprinted by the archdiocese's Catholic Telegraph newspaper, Bedini also forgave his attackers and urged them to reform their lives, for "the consequences of evil are for him who harbors it in his heart or seeks to propagate it."176

Catholics continued to blame atheists for attacking Bedini, but elsewhere most Cincinnatians came to support the Freemen's views on democratic liberalism and dissent. After Prosecutor Dickson dropped charges against Freemen spokesman Friedrich Hassaurek, the young rhetorician dramatically swore out a warrant against Judge Spooner, Police Chief Lukens, and 108 watchmen. The affidavit marked a complete and ironic reversal of the original December trial, for now Hassaurek charged city officials with inciting riotous violence. ${ }^{177}$ This legal response signaled the Freemen's growing ability to shape public discourse, exploit unstable party lines, and fold themselves into the embrace of American liberalism. Significantly, Whigs, avowed nativists, freethinkers, and even frustrated Democrats all adopted Hassaurek's narrative

${ }^{174}$ Archbishop John Purcell, letter to Archbishop Anthony Blanc, December 30, 1853, Archdiocesan Records, Electronic Archival Calendar, University of Notre Dame Archives (Notre Dame, Ind.).

${ }^{175}$ Connelly, Visit of Archbishop Gaetano Bedini, 109; Archbishop John Purcell, letter to Archbishop Anthony Blanc, December 30, 1853, Archdiocesan Records, Electronic Archival Calendar, University of Notre Dame Archives (Notre Dame, Ind.); Archbishop Gaetano Bedini, letter to Archbishop John Purcell, January 2, 1854, Archdiocesan Records, Electronic Archival Calendar, University of Notre Dame Archives (Notre Dame, Ind.).

${ }^{176}$ Archbishop Gaetano Bedini, letter to Archbishop John Purcell, January 2, 1854, Archdiocesan Records, Electronic Archival Calendar, University of Notre Dame Archives (Notre Dame, Ind.). See also Mairose, "Nativism on the Ohio," 95.

${ }^{177}$ Mairose, "Nativism on the Ohio," 85-87; Gazette, January 6, 1854. 
as the definitive account of the Bedini Affair. ${ }^{178}$ By taking their grievances to court rather than to the streets, the Freemen further distanced themselves from their old socialist reputations. After 1848 ideals failed to gain traction in America, the Germans fell back on the tenets of political liberalism. Now, in light of the Christmas conflict, the Freemen skillfully linked natural rights liberalism to American constitutional principles and pointed out the growing gap between democratic ideology and autocratic practice in Cincinnati. Within weeks, native-born residents would burn the Nuncio's effigy, but the Freemen were nowhere to be found. The time for antiBedini protests was over, the Germans countered, for their march had roused citizens and initiated the city’s return to constitutional principles. ${ }^{179}$

This rowdy effigy burning completed Bedini's transformation from a living reminder of European oppression to a symbol of American corruption. Inspired by the indignation meeting's resolutions and infuriated by daily court revelations of unconscionable police violence, an estimated four thousand native-born protestors swarmed downtown Cincinnati's streets and squares on January 14 to denounce Snelbaker, Spooner, and the police. At first glance, the protest seemed modeled on the Freemen's earlier effort since marchers wove through the streets carrying anti-Catholic transparencies, mock gallows, and an effigy of the Nuncio dressed in black pontifical vestments. The demonstrators then wailed and booed as they passed Purcell's residence - even though Bedini himself had left the city two weeks earlier - before erupting in frenzied excitement as the Nuncio's burning effigy began to shine against the dark night sky. ${ }^{180}$ Yet Cincinnatians cheered the triumph of freedom over petty tyranny as much as Bedini's personal downfall. Tellingly, protest leaders carried a three-sided transparency that made no

\footnotetext{
${ }^{178}$ Some newspapers outside of Cincinnati also came to base their accounts of the "Bedini Affair" on the Freemen's Address and court claims. See Perrysburg Journal (Ohio), January 23, 1854.

${ }^{179}$ Daily Enquirer, January 15, 1854; Ripley Bee (Ohio), January 21, 1854.

${ }^{180}$ Daily Enquirer, January 15, 1854.
} 
mention of Bassi but instead called out "Down with Bedini!" "No Popery!" "Pitch In!" 181 During the Kirkland and Bedini disturbances, they claimed, Snelbaker, his Democratic minions, and the city's mainly Catholic police force had protected the interests of Purcell and the Pope at the expense of the basic American ideals of fairness and equality under the law. ${ }^{182}$ Lukens's alleged order for the watchmen to "pitch in" to the Freemen provided an example of police autocracy and a powerful reminder that autocratic power, whether wielded by Snelbaker, the "Slave Power," or other conspiratorial interests, invariably resulted in repression and violence. ${ }^{183}$ Native-born Cincinnatians remained skeptical of Bedini's past and suspicious of Purcell's motives, but they were more concerned by Snelbaker's arbitrary interpretations of law and order. In a final and dramatic gesture of defiance, these American freemen denounced the tyrant in their midst by carrying off Bedini's still-burning effigy and casting it down the police watch-house steps. $^{184}$

This symbolic rejection of Snelbaker's leadership presaged major electoral gains for the new political reform ticket that catered to the growing liberal sentiments of Cincinnati voters. Despite widespread public fury and weeks of scandalous court testimony, few officials were held responsible for the police crackdown: William Spooner remained as police judge and only a small percentage of the watchmen were dismissed or tried in criminal courts. ${ }^{185}$ After Lukens's resignation, in fact, the police returned to raiding gambling houses and other immoral properties by the end of January. ${ }^{186}$ These defenses of Christian values attracted little controversy, but memories of Snelbaker's miscarriage of justice did not fade so easily. Lukens became derisively

\footnotetext{
181 Ibid.

182 Daily Enquirer, January 25, 1854; Grimsted, American Mobbing, 220-234.

${ }^{183}$ Daily Enquirer, January 10, 1854.

${ }^{184}$ Daily Enquirer, January 15, 1854; Mairose, "Nativism on the Ohio," 92-93.

185 Mairose, "Nativism on the Ohio," 91-92.

${ }^{186}$ Daily Enquirer, January 29, 1854.
} 
known as the "Little Kickapoo Chief" and a local poet dedicated his latest work, "Pitch-In," to the watchmen, while residents of neighboring Covington, Kentucky, sarcastically asked for the Cincinnati Mayor's help in preventing their upcoming Bedini effigy burning from devolving into a riot. ${ }^{187}$ Frustrated by the city administration's continued stonewalling and energized by their opponents' botched rollout of the proposed Kansas-Nebraska Act, anti-Democratic voters formed a loose coalition of reform-minded Whigs, nativists, and Freemen. United by their hatred of Democratic policy and common faith in transparent government, these reformers were swept into power by convincing margins during the 1854 elections. ${ }^{188}$

These local electoral swings underscored the contentious and often contradictory nature of antebellum democracy and citizenship. Endowed with both a Declaration of Independence that espoused universal values and a more hierarchical Constitution that simultaneously promoted civil liberties and limited government, Americans struggled to define democracy and set proper limits on free speech and religious expression. ${ }^{189}$ For Snelbaker and Purcell, Kirkland's harangues and the Freemen's libelous assaults on Bedini represented hateful speech that endangered the peace and security of Cincinnati residents. Yet liberal exiles and partisan critics countered that Catholic orthodoxy and the Mayor's forceful interventions posed far greater threats to American liberty than any non-violent preacher or protestor. Public violence, as well as subsequent police brutality, was cast as either a virtuous defense of the peace or a necessary struggle to defend the rights of freemen. Similarly, neither native- nor foreign-born voters ever provided a full description of the rights and responsibilities required by American citizenship. Instead, the lines between citizen and alien, as well as friend and foreigner, remained permeable and ever-changing. Freemen, once seen as rabblerousing socialists, later presented

\footnotetext{
${ }^{187}$ Mairose, "Nativism on the Ohio," 91-93.

${ }^{188}$ Ibid., 104-115.

189 Endres, "Reassessing the Visit," 13-16.
} 
themselves as the prophets of American democratic renewal. Narratives of the Bedini Affair, while certainly shaped by pressing religious and partisan concerns, also raised key questions about the shape and scope of antebellum government. Had the Founders envisioned a republic of restraint and order, Cincinnatians asked, or a direct democracy of constant agitation and conflict? Native-born residents temporarily reconciled these debates and competing narratives by blaming the Christmas conflict on incompetence and corruption rather than popular beliefs and political institutions. Indeed, after all the court hearings, effigy burnings, and angry meetings, public faith in America's unique and exceptional status remained firmly intact. Native-born residents ultimately saw no need to answer their own questions about the Founders' original constitutional intent, for they instead focused on the alleged misdeeds of Snelbaker, Lukens, and Spooner. The street clash was not the product of flawed democracy, they concluded, but the natural result of mismanagement. Even the Democratic Daily Enquirer, the Gazette pointed out, ultimately concluded that Cincinnatians had erred in "confiding the administration of vital, moral, social, pecuniary, and all the other domestic interests of society, to the care of weakminded, self sufficient, tyranical [sic] and corrupt officials. ${ }^{, 190}$ Reforming Cincinnati involved replacing these individuals with new and virtuous republican officials who respected basic standards of decency and practiced Protestant charity. The Freemen's agnosticism still troubled native voters, but the Germans' resistance to tyranny made them useful political partners. ${ }^{191}$ As Hassaurek's counsel, Timothy Walker, succinctly explained, "the name of Freeman is better than Jesuit."192 Free of Catholic political meddling and Democratic corruption, Cincinnati, the "Queen City of the West," would finally achieve its destiny as a shining global icon of peace and prosperity.

\footnotetext{
${ }^{190}$ Daily Enquirer quoted in the Gazette, January 9, 1854.

${ }^{191}$ Mairose, "Nativism on the Ohio," 110-114.

192 Daily Enquirer, January 10, 1854. See also Grimsted, American Mobbing, 228.
} 
Despite this public praise, the Freemen remained skeptical of native-born republicans and subtly sought to correct their adopted homeland's exaggerated sense of national destiny. The United States could ultimately become a sterling example of freedom and democracy, they explained, but at the moment America remained far from exceptional. Invocations violated the separation of church and state, police violence ruled, and direct democracy remained stifled. In editorials and court testimony, the Germans downplayed their radical heritage and instead praised American ideals in hopes of connecting Cincinnatians to the Atlantic-wide fight for freedom. These efforts gained the Freemen a tenuous hold in Cincinnati republican society, but they failed to fully displace nativist fears or build support for the Germans' cosmopolitan views of constitutionalism and civil rights.

Meanwhile, Catholics continued to rail against the Freemen's embrace of human agency, which Church leaders portrayed as a perversion of organized society and authentic freedom. For the Freemen, as well as many American liberals, human liberty reflected full personal autonomy - the ability to think, speak, and act without state influence. Antebellum parishioners strongly objected to this standard, as historian John McGreevy noted: "Catholics saw moral choice and personal development as inseparable from virtues nurtured in families and churches." ${ }^{\prime 93}$ In Archbishop Purcell's view, Catholicism did not require its adherents to suspend their use of reason, but rather asked them to confront humanity's weaknesses. Since passion, immaturity, and selfishness could all lead an individual to commit grave sins and abuses, Church members were encouraged to lean on centuries of collective wisdom to help filter out biases and discern right from wrong. ${ }^{194}$ In contrast, the Freemen appeared as misguided skeptics who wandered off on a hopeless quest to find meaning apart from God's will by overthrowing established and necessary

\footnotetext{
${ }^{193}$ McGreevy, Catholicism and American Freedom, 36.

${ }^{194}$ Daily Enquirer, November 24, 1853.
} 
hierarchies in the name of so-called "liberty." Catholics across the Atlantic contrasted the reasoned approach of Pius IX to the reactionary methods of Louis Kossuth, Alessandro Gavazzi, and others: while the Holy Father recognized that social reforms succeeded only with the aid of Divine power, as exercised by the Church, radicals uprooted society, denied the sacred right of established government, and described constitutions as secular contracts rather than spiritual commissions. As their spectacular revolutionary failures proved, these democrats could do nothing apart from God. ${ }^{195}$ Unlike their agnostic opponents, who fruitlessly pursued freedom from coercion, laymen obeyed the divine law - as revealed through revelation, tradition, and nature - to gain the freedom to live meaningful and virtuous lives. This "true" freedom supported established constitutional democracies grounded in ordered liberty, but undermined states that substituted majority will for natural law. Thus, in the view of American priest Jeremiah Cummings, any comparison between the virtuous Founding Fathers and the socialist European radicals of 1848 produced a great "insult to our noble and glorious country." ${ }^{, 196}$ Purcell agreed, but he also saw Bedini's violent reception in light of America's dangerous drift toward unfettered democracy. As he later reported to Rome, only the city's quick police response had prevented this public display of unrestrained "freedom" from endangering innocent lives. ${ }^{197}$

The Christmas clash thus marked a collision of competing cultural narratives and political principles that occurred during a period of partisan reconfiguration and democratic upheaval. By explaining the significance of the disturbance in the context of antebellum immigration and nativism, previous scholars have obscured the diversity and dynamism that defined this brief

\footnotetext{
195 Orestes Brownson, letter to Father Jeremiah Cummings, January 22, 1848, Orestes Brownson Papers, Electronic Archival Calendar, University of Notre Dame Archives (Notre Dame, Ind.); Charles de Montalembert, letter to Orestes Brownson, January 28, 1850, Orestes Brownson Papers, Electronic Archival Calendar, University of Notre Dame Archives (Notre Dame, Ind.).

${ }^{196}$ Father Jeremiah Cummings quoted in McGreevy, Catholicism and American Freedom, 37.

197 Archbishop John Purcell, letter to Cardinal James Fransoni, January 12, 1854, Archdiocesan Records, Electronic Archival Calendar, University of Notre Dame Archives (Notre Dame, Ind.).
} 
inter-party period. In Cincinnati, anti-Bedini protestors crossed old partisan, religious, and ethnic lines to assert the importance of American liberalism and forge alliances that foreshadowed the wartime Republican coalition of abolitionist Germans, former Whigs, and nativists. Opposing groups also developed vastly different interpretations of the "riot" based on their views of religion, republican virtue, and governmental intervention. Local, national, and international forces were all in play, as the Freemen's Address linked Koszta with Kirkland and native-born voters embedded Atlantic critiques within a self-serving narrative of American progress. Horrified by police violence, Cincinnati reformers and Freemen articulated views on human agency and democratic dissent that stood in contrast to Catholic hierarchical obedience and Democratic law and order. As one editorial argued weeks after the riot, "let the lovers of peace, of law and order, unite to give unmistakable assurance of the certainty of the supremacy of law." ${ }^{198}$ Few residents disagreed with these sentiments, but the question remained: which definition of law and order should be used? Beneath the veil of American exceptionalism and constitutionalism lay a country struggling to assert its place in the Atlantic World and define the proper limits of liberal democracy.

${ }^{198}$ Daily Enquirer, January 22, 1854. 


\section{Conclusion}

\section{The Many Affairs of Gaetano Bedini}

The Cincinnati Freemen's liberal views and transatlantic rhetoric reverberated in immigrant communities across the nation, forcing native-born residents in cities such as Wheeling, New Orleans, and New York to debate the meanings of American hospitality and the rule of law. Alarmed by growing anti-Bedini sentiment, Michigan Senator Lewis Cass feared for the Nuncio's safety, his son's career, and his country's reputation. On January 23, 1854, the Michigan statesman rose before the United States Senate to condemn the Nuncio's opponents and remind listeners of their country's exceptional status. The Senator never mentioned his son by name, rather noting that "a near and dear relative now in Rome" vouched for Bedini's character and denounced Gavazzi’s lies. Echoing Mayor Snelbaker, the Michigan Democrat urged citizens to set aside their "regrettable" protests and treat the Nuncio with respect. In the debate that followed, both Democrats and Whigs followed Cass's lead in speaking out against anarchy and street violence, but their apparent unity failed to bridge deep ideological and sectional divides. Applause from the public galleries rang out in favor of Democrat John Weller's defense of civil liberty, while Northern senators scoffed at Georgian William Dawson's suggestion that Bedini could have toured the South without fear of public unrest. ${ }^{199}$ Beyond Capitol Hill, Italian immigrants and nativists brushed off Cass's criticisms and continued protesting the conspiratorial "Butcher," while Catholics praised Bedini's resolve. These clashing narratives continued to be revised for years after the Nuncio's departure, creating three intertwined conflicts over American democracy, religion, and citizenship.

\footnotetext{
${ }^{199}$ Congressional Globe, $33^{\text {rd }}$ Congress, $1^{\text {st }}$ Session (1854), 223-227. See also the Biographical Directory of the United States Congress, http://bioguide. congress.gov; Endres, "Reassessing the Visit," 9; Connelly, Visit of Archbishop Gaetano Bedini, 122-126.
} 
Know Nothing leaders and academic historians later narrowed these competing cultural and political narratives into unified accounts that portrayed America's "Bedini Affair" as an example of political nativism. But in reality, the Affair featured multiple groups talking past each other in cities such as Cincinnati, New Orleans, and New York, each faction focusing on issues related to democracy, citizenship, religion, and the rule of law. Transatlantic trends and personalities collided with domestic issues, foreign myths gave way to Know Nothing propaganda, and contested memories of the Nuncio's visit reflected competing views of republican liberty. By analyzing the nativists' sensationalized anti-Bedini accounts alongside the arguments and actions of their Democratic, Catholic, Whig, and foreign-born competitors, I reveal the political, ethnic, and social uncertainties that defined midcentury America. The "Bedini Affair" is both a historical and historiographical misnomer, for the Nuncio’s visit catalyzed a series of democratic affairs that ultimately focused less on Bedini than on the demographic divides, religious tensions, and civil contradictions he symbolized.

Early reports of the Cincinnati disturbances reflected these inconsistencies by simultaneously criticizing the Nuncio and denouncing his opponents. In Washington, the National Era attacked the Vatican for dispatching a suspected autocrat to the United States, only to add that the Christmas clash represented a grave breach of national conduct. Despite Bedini's alleged crimes, residents had no reason to challenge police authority or engage in street fights. "Let the Nuncio and his master be hated," the Era argued, "but let American citizens respect themselves and their institutions, and the general cause of Freedom, too much, to think of gratifying their just resentment . . by a violation of Law." 200 The true genius of America lay not in its divinely ordained civilization or balanced governmental structure, but in its citizens'

${ }^{200}$ National Era, January 5, 1854. 
undying devotion to the rule of law. ${ }^{201}$ In an era in which many citizens argued that the United States should protect freedom by intervening in foreign affairs, the Era reminded its readers that the cause of liberty still faced setbacks at home. As long as residents mistreated visitors such as Bedini and failed to uphold basic constitutional principles, American lectures on the benefits of democracy would fall on deaf European ears. To live up to exceptionalist standards and support freedom, Americans needed to embrace restrained and enlightened forms of republican behavior. $^{202}$

Opposing editors defended exceptionalism by blaming the riots on spirited and ungracious immigrants. The Protestant editor of Virginia's Wheeling Gazette, for instance, contrasted his dignified response to the Nuncio's January 4 arrival in the city with the incendiary and libelous reactions of his radical German neighbors. After handbills describing the supposed crimes of the "monster" Bedini were plastered across Wheeling, he refused to publish the Address and instead traveled through town tearing down the placards. Other native-born citizens followed suit, and residents reported that they "did not see a Protestant who did not condemn and regret" the inhospitable signs. ${ }^{203}$ Editors in New York City also denounced these anti-Bedini handbills, arguing that "in no case do we believe that they have originated with Americans." Instead, the New York Commercial Advertiser blamed émigrés "who cannot appreciate liberty as constitutionally enjoyed in these United States." ${ }^{204}$ Drawing on depictions of European revolutionists as weak children in need of mature republican guidance and support, editorials

\footnotetext{
${ }^{201}$ Antebellum Americans saw the "law" not simply as a series of regulations to be enforced, but also as a collection of institutional and social practices that ensured republican government by providing standard mechanisms for arbitrating civic disagreements. Native-born Northern residents viewed both European radicalism and Southern sectionalism as existential threats to reasoned political deliberation and thus "law and order" more generally. See Phillip Paludan, "The American Civil War Considered as a Crisis in Law and Order," The American Historical Review 77 (1972): 1013-1034.

${ }^{202}$ Gemme, Domesticating Foreign Struggles, 5-7, 16, 58-73.

${ }^{203}$ Wheeling Gazette quoted in the Philadelphia Public Ledger, January 12, 1854. See also Connelly, Visit of Archbishop Gaetano Bedini, 115.

${ }^{204}$ New York Commercial Advertiser quoted in the Baltimore Sun, January 21, 1854.
} 
described how these recent arrivals remained either unwilling or unable to embrace law and order. ${ }^{205}$ Rather than enjoy the freedoms and opportunities of American citizenship, excitable émigrés had instead carried their Continental grudges and debates across the Atlantic. Innocent Americans were now caught in the crossfire between radical exiles and religiously orthodox prelates and immigrants. ${ }^{206}$ The émigrés' apprenticeship in liberty had failed: despite the example of native-born Protestants, who respectfully welcomed Bedini despite differences of faith and political principles, socialist and agnostic immigrants continued to plan riots and assassinations. Editors drew on these stereotypical portrayals of immigrant activism to reinforce the exceptionalist belief that America's problems were the products of foreign meddling. ${ }^{207}$

These fears were seemingly confirmed by New Orleans placards calling for the city's competing ethnic groups to unite and avenge the deaths of Bolognese patriots. After Christmas, news of the Cincinnati disturbances mixed with rumors of the Nuncio's imminent arrival and suspicions about the city’s influential Catholic community to create a crisis atmosphere. ${ }^{208}$ Anonymous red handbills written in English, French, Italian, and German appeared on neighborhood fences and walls to remind immigrants of Bedini's alleged reign of terror in Bologna. Each paragraph was carefully edited to provoke its intended audience: the handbill's English section contrasted the Nuncio's scalping of a "patriotic Katholic [sic] priest" with Catholic Ireland's heroic resistance against British tyranny, while further down the page a brief Italian exhortation reminded readers to "receive him [Bedini] as is fit. Do your duty." In contrast to the Cincinnati Freemen, whose Address praised liberal constitutional principles and cast German immigrants as the true defenders of exceptionalist rights, New Orleans activists focused

${ }^{205}$ Roberts, Distant Revolutions, 14-18; Gemme, Domesticating Foreign Struggles, 13-21, 39-46.

206 Weekly Herald, December 31, 1853.

${ }^{207}$ Billington, Protestant Crusade, 322-336; Anbinder, Nativism and Slavery, 15-19.

${ }^{208}$ All quotes from and descriptions of the New Orleans Address in this and the following two paragraphs come from the New Orleans Crescent, January 9, 1854, quoted in the Weekly Herald, January 21, 1854. 
on righting Continental wrongs. The handbill's authors made no effort to identify themselves as American citizens or justify their proposed actions based on constitutional principles and exceptionalism. ${ }^{209}$ Few allusions to cosmopolitan ideals or global republican solidarity were made, for the handbill instead focused on Bedini's unconscionable cruelty. "You will treat him," francophone residents were told, "as men treat a wild beast." Cincinnati Germans presented themselves as prophets of progress who looked forward to America's liberal and exceptionalist future, but Louisianan protestors looked back over failed revolutions. Separated by language, ethnicity, and nationalism, these immigrants were united by their desire to strike a blow against the old authoritarian oppressors of Europe. ${ }^{210}$

The handbill's sensationalist rhetoric highlighted the need to bring the "Butcher of Bologna" to justice, whether in the courtroom or in the court of public opinion. Americans had rightfully welcomed past visitors such as Lafayette and Louis Kossuth, the placard's authors argued, but now national leaders and local elites were feting the despotic Nuncio with banquets and honors. Bedini's heinous crimes were so contrary to the standards of human decency, however, that not even the principles of republican hospitality could protect him. Acting as de facto prosecutors, the handbill's authors supplied graphic “evidence” of the Archbishop's cruelty. Gavazzi's account of Ugo Bassi's death was further edited and expanded to include scores of other freedom fighters supposedly murdered on the Nuncio's watch. "Men who have hearts, friends of humanity, freemen," the French Address cried, "will you suffer this insulter of the people, this audacious wretch, to profane our soil?" So long as a merciless tyrant such as Bedini remained the welcomed guest of American leaders, activists insisted, residents would

\footnotetext{
${ }^{209}$ Archbishop Anthony Blanc described the activists as French radicals and German Freemen. See Archbishop Anthony Blanc, letter to Archbishop John Purcell, January 12, 1854, Archdiocesan Records, Electronic Archival Calendar, University of Notre Dame Archives (Notre Dame, Ind.).

${ }^{210}$ Levine, Spirit of 1848, 46-48; Roberts, Distant Revolutions, 4-13; D’Agostino, Rome in America, 23-32.
} 
continue to convene their own courts in the streets. Native-born Americans seemed set on worshipping exceptionalism and the law, but émigrés would not suffer Bedini's provocative visit in silence. To avenge fallen martyrs and uphold the basic standards of human life and liberty, the residents of New Orleans readied themselves to oppose Bologna's "Butcher."

Native-born New Orleans residents were horrified by these "libelous" handbills and forceful claims, which were interpreted as further proof of the exiles' disregard for proper republican restraint. The placard's misspellings and poor grammar, the New Orleans Crescent argued, proved that its authors had a rudimentary knowledge of Italian and English. "It is clear," the paper declared, that the authors could not "raise English enough to convey otherwise than most ludicrously their bloody purposes. Men, then, who have not learnt even our language, are about to get themselves up to overturn our laws!" These "strangers" seemed equally unfamiliar with America's commitment to constitutional government, its insistence on the presumed innocence of all accused persons, and its status as a peaceful republican sanctuary. The émigrés' plan to circumvent the legal system by rioting against Bedini, all in the name of Ugo Bassi and other Bolognese allegations that had never been substantiated, was a clear insult to national customs. The United States stood apart from the violent, reactionary, and vengeful world of European politics, but now foreign agitators aimed to upset this delicate balance and settle old scores against the Catholic Church. "But at least these wise rioters have given you a week's notice," the Crescent lectured residents, so "profit by it; and do not let your city be in any manner endangered or disgraced.” Little mention was made of Cincinnati’s Bedini Affair, but the two cities remained linked by their liberal exceptionalist beliefs. ${ }^{211}$ While the Freemen gained public support by positioning themselves as champions of the rule of law, foreign-born

${ }^{211}$ Connelly, Visit of Archbishop Gaetano Bedini, 112. In addition to the Crescent, the Daily Picayune and Courrier de la Louisiane also denounced the placards. 
Louisianan activists were seen as subversive socialists. In each city, public opinion swung to the side that best articulated its faith in domestic tranquility and constitutional liberty.

Catholic bishops applauded New Orleans's strong stand against mobocracy even as they saw continued public resistance as an opportunity for spiritual purification. In particular, New Orleans Archbishop Anthony Blanc was pleased by his neighbors' defense of Bedini's personal character and diplomatic immunity. After hearing of the controversial handbill, in fact, the city's mayor ordered residents to tear down the placards and readied police officers to protect the city from foreign-born "rioters." This swift condemnation of anti-Bedini rhetoric, Blanc proudly wrote Archbishop John Purcell, stunned and silenced the Nuncio's atheist foes. ${ }^{212}$ Rather than protect the faux liberty espoused by European infidels and socialists, city authorities had wisely preserved civic order by placing reasonable limits on inflammatory speech. Yet Bedini never personally tested the limits of New Orleans hospitality, since his itinerary was cut short by orders recalling him to Rome. In a letter to Blanc, the Nuncio expressed his disappointment at the change in plans and reassured his fellow prelate that his riotous tour had still benefitted the Church. Since souls are sanctified through trials and tribulations, Bedini reminded his brother bishop, atheist protestors were unwittingly strengthening the very Church they sought to destroy. ${ }^{213}$ American bishops shared the Nuncio's faith in suffering and salvation, offering up their frustrations as penance even as they steeled their souls for possible martyrdom. ${ }^{214}$ But as

\footnotetext{
${ }^{212}$ Archbishop Anthony Blanc, letter to Archbishop John Purcell, January 12, 1854, Archdiocesan Records, Electronic Archival Calendar, University of Notre Dame Archives (Notre Dame, Ind.).

${ }^{213}$ Archbishop Gaetano Bedini, letter to Archbishop Anthony Blanc, February 1, 1854, Archdiocesan Records, Electronic Archival Calendar, University of Notre Dame Archives (Notre Dame, Ind.); Archbishop Gaetano Bedini, letter to Archbishop John Purcell, January 8, 1854, Archdiocesan Records, Electronic Archival Calendar, University of Notre Dame Archives (Notre Dame, Ind.).

${ }^{214}$ Archbishop John Purcell, letter to Archbishop Anthony Blanc, December 30, 1853, Archdiocesan Records, Electronic Archival Calendar, University of Notre Dame Archives (Notre Dame, Ind.); Archbishop Francis Kenrick, letter to Archbishop John Purcell, August 5, 1854, Archdiocesan Records, Electronic Archival Calendar, University of Notre Dame Archives (Notre Dame, Ind.).
} 
prelates prepared to stand in judgment before the risen Christ, Lewis Cass rose on the Senate floor to condemn his countrymen's inhospitable treatment of Bedini.

Cass cast the Nuncio as a dignified diplomat whose rowdy reception in America had damaged the global campaign for liberty. The spiritual aspects of Bedini's trip were beyond the purview of the Senate, the Michigan Democrat argued, but his status as the diplomatic representative of the Papal States entitled him to recognition. Taking aim at both the Nuncio's immigrant and nativist critics, Cass reminded listeners that Bedini, "a man of the highest character and standing," had traveled across the Atlantic with a signed letter from Pope Pius. This letter "is a common procedure in Europe," the statesmen continued, "and it is intended as a compliment and a mark of good feeling towards the people of the United States." 215 Yet Americans repaid the Vatican's thoughtful gesture with assassination attempts, violent protests, and ceaseless calumnies. Cass paid little attention to whether the protests were inspired and organized by foreign- or native-born citizens; in the world's eyes, Bedini had been wrongfully shamed by the entire American citizenry. Serving as the world's exemplar of republicanism remained a solemn national responsibility, for while the country's freedoms and opportunities inspired countless foreign reformers and émigrés, its shortcomings strengthened autocrats. Reports of the Bedini disturbances, the statesman warned, would provide new fodder for European philosophers and politicians "from the western shore of England to Siberia" who claimed that popular governments produced chaos and anarchy. "Acts of violence which override the laws," Cass concluded, "do more injury to the cause of republican institutions in the old world, than any other event." ${ }^{216}$ In their rush to denounce the Nuncio and avenge fallen

${ }^{215}$ Congressional Globe, $33^{\text {rd }}$ Congress, 223. See also Connelly, Visit of Archbishop Gaetano Bedini, $122-$ 125.

$$
{ }^{216} \text { Congressional Globe, } 33^{\text {rd }} \text { Congress, } 223 .
$$


Italian revolutionaries, protestors resembled the thoughtless reactionaries and heartless autocrats they claimed to abhor.

The Senator called on the Nuncio's critics to abandon their street barricades and embrace peaceful republican values. Anti-Bedini protestors, Cass charged, clung to outdated views of democracy that overemphasized the importance of popular resistance against tyranny. In serious cases, of course, opposing oppression remained the right, if not duty, of every citizen. Yet protestors often acted as if democracy gave them free rein to threaten life, property, and lawful civic authority. Mistaking slander for free speech, these protestors endangered the very liberties their colonial forefathers once fought to protect. The days of tarring British officials and terrorizing redcoat soldiers were past, for current patriots needed to legitimize their fledging government by conducting themselves as upstanding citizens. Rather than taking every public conflict into the streets, residents should respect the rule of law, embrace the electoral cycle, and civilly engage in public discussions and debates. Fighting for freedom required strength and bravery, but the ongoing battle to secure liberty now required Americans to develop moderation and restraint. "The best safeguard and security in cases of violent excitement is to be found in a wholesome public opinion," Cass contended, for "like truth, it is mighty, and will prevail in this land of freedom and intelligence. ${ }^{217}$ By investigating Bedini’s diplomatic credentials and denouncing the Nuncio's opponents, the Senator hoped to prick his country's conscience and remind citizens of the rights and responsibilities of republicanism. Bolognese tales and political radicals had momentarily upset the civic order, Cass optimistically concluded, but the vast majority of Americans remained committed to preserving the peace and protecting liberty. ${ }^{218}$

\footnotetext{
${ }^{217}$ Congressional Globe, $33^{\text {rd }}$ Congress, 223. See also Smith, The Dominion of Voice, 40-52.

${ }^{218}$ Congressional Globe, $33^{\text {rd }}$ Congress, 223, 225.
} 
Southern senators built upon Cass's condemnation of immigrant activists, portraying radical 1848 émigrés as threats against popular government. "In every instance," Georgia’s William Dawson observed, "it has been the foreign influence of the country that has been attempting to bring into degradation the Constitution and the laws of the land." ${ }^{219}$ Echoing Catholic leaders, both Dawson and Mississippi’s Stephen Adams charged émigrés with substituting anarchy for true freedom. American liberty freed citizens from the oppressive abuses of autocracy, they contended, but it did not dissolve basic social bonds nor excuse residents from obeying the rule of law. ${ }^{220}$ European abolitionism, atheism, and socialism, in contrast, encouraged adherents to substitute private opinions and judgments for public republican responsibilities. "All sorts of isms, all sorts of feelings are combining themselves together," Dawson explained, "not in subordination to law, but in subordination to feeling.",221 Standard governmental checks and balances had collapsed in the face of majority opinion, leading the Georgian to conclude that "the period will come when the people will combine and do as they please."222 These ominous words highlighted the growing fear among political elites that the Bedini Affair and other mob actions were symptomatic of the country's shift towards majority tyranny. ${ }^{223}$ Yet the exceptionalist dream still survived - albeit with a sectional slant. If the rest of the country followed the South's example and embraced hierarchical rule, Dawson suggested, national greatness would follow.

Dawson's regional bias and distrust of popular governance drew scorn from dissenting senators, many of whom saw free speech and public agitation as the hallmarks of healthy

\footnotetext{
219 Ibid., 224.

${ }^{220}$ Ibid., 224-225.

${ }^{221}$ Ibid., 224. Emphasis original.

222 Ibid., 224.

${ }^{223}$ Ironically, the phrase "tyranny of the majority" was popularized by a foreign visitor, Alexis de Tocqueville, in 1835. See Harvey Mansfield and Delba Winthrop, trans., Democracy in America (Chicago:
} University of Chicago Press), 239-241. 
democracy. Illinois's Stephen Douglas, who earlier in the day had introduced a revised version of the Kansas-Nebraska Act, ironically charged Dawson with needlessly inflaming sectional tensions. Massachusetts Senator Edward Everett concurred, arguing that "the feeling on this subject [Bedini's visit], spontaneously arising in every well-regulated mind, is not bounded by any sectional lines." 224 Yet "well-regulated" republican minds, others retorted, formed through debate and deliberation; public demonstrations, lectures, and protests all fostered democracy by allowing citizens to air their grievances and exercise their rights. ${ }^{225}$ In particular, John Pettit cited the Cincinnati disturbances as evidence that his senatorial colleagues were too quick to condemn the protestors. "So anxious were [the city authorities] to prevent an outbreak and violation of the law," the Indianan asserted, "that they themselves violated the law." ${ }^{226}$ California's John Weller questioned Gavazzi's veracity and wondered aloud whether the protestors had bolstered republicanism: "if he [Bedini] were guilty of even one half of the crimes that have been charged," the Senator declared to thunderous applause from the galleries, "the people were right in expressing their opinions." ${ }^{227}$ Cass's embarrassing tales of national inhospitality were false alarms, for in reality the Bedini Affair underscored the nation's commitment to civic virtue and deliberative democracy.

While critics criticized Cass's overstated account of the Bedini Affair, they remained unable to articulate a consensus view of democracy. In Weller's view, the Michigan statesman's efforts represented attempts to "manufacture" public opinion. ${ }^{228}$ "When was the Senate converted into a laboratory?" the Californian cried, and "when did the people intrust us with the

${ }^{224}$ Congressional Globe, $33^{\text {rd }}$ Congress, 221-224.

${ }^{225}$ Altschuler and Blumin, Rude Republic, 151; Ryan, Civic Wars, 91-124; Stephen Hartnett, Democratic Dissent and the Cultural Fictions of America (Urbana: University of Illinois Press, 2002), 176.

${ }^{226}$ Congressional Globe, $33^{\text {rd }}$ Congress, 226.

${ }^{227}$ Ibid., 226.

${ }^{228}$ Ibid., 223, 225, 227. 
sovereign power of speaking the public sentiment of America?"229 In a proper democracy, Weller argued, legislators were elected to voice not their own opinions, but rather the views of their constituents. Cass could personally condemn the protests, but he went too far in claiming his beliefs reflected the views of the entire American electorate. The Michigan senator had no business bringing the Bedini Affair before the Senate, in fact, because federal mandates already protected foreign dignitaries from violence. Stephen Adams of Mississippi took a different tack, arguing that a Senate inquiry would violate states' rights and illegally attempt to "regulate public opinion. ${ }^{, 230}$ While Cass claimed that the Nuncio's diplomatic status placed him under federal protection, Adams saw riot control as a state concern. Foreshadowing secession, the Senator declared that "there is very great danger that we may in time forget that there are States in this Union, and that this Federal Government is one of delegated and limited powers." ${ }^{231}$ Adams's defense of federalism showed that the antebellum sectional conflicts over slavery and commerce were closely related to continuing uncertainty over the definition of democracy. ${ }^{232}$ Decades after the Constitutional Convention, leaders in cities such as Cincinnati and Washington still struggled to describe the proper relationship between citizens and their government; despite its foreign overtones, the Bedini Affair exacerbated this domestic conflict over constitutional liberties and federal power. Exceptionalist rhetoric may have described the United States as a bastion of freedom in an uncertain world, but antebellum Americans remained divided over how to translate democratic theories and principles into cultural and governmental practices.

Rather than reflecting on these broad issues, however, newspaper editors embraced exceptionalism and described the Senate debate as a distraction from real legislative priorities.

\footnotetext{
${ }^{229}$ Ibid., 227.

${ }^{230}$ Ibid., 225.

231 Ibid., 225.

${ }^{232}$ Holt, Political Crisis, 136-159; Anbinder, Nativism and Slavery, 43-53.
} 
“Solemn homilies were read," Washington's National Era sarcastically noted, and "one might have supposed ... that the whole country was convulsed with excitement, and the arm of civil authority was powerless." ${ }^{233}$ Writers criticized Cass for slandering the American people, exaggerating the crisis, and even instigating further violence. Others believed that ulterior motives drove the debate: Cass worried that the Bedini "riots" would damage his son's political prospects, the New York Weekly Herald suggested, while cross-town correspondents at the Tribune believed that presidential aspirants such as Stephen Douglas were seeking opportunities to portray themselves as dignified statesmen. ${ }^{234}$ The New York Express similarly faulted the senators" elitist views of civic "rioting” and their gullible acceptance of Bedini's innocence. "Padre Gavazzi," the paper retorted, "is as truthful a person as the Ex-Governor of Bologna.",235 Editors also criticized Cass's suggestion that Americans were failing to provide Bedini with a respectful republican reception. In other words, America's reputation remained unscathed, no national Bedini controversy existed, and no legislative remedy was required. ${ }^{236}$

Secretary of State William Marcy agreed with these exceptionalist assessments, claiming that American citizens disapproved of the exiles' protests against Bedini. The Secretary’s rhetorical campaign began in Washington, where he provided senators with a copy of the Nuncio’s official State Department file. One item, however, remained suspiciously unaccounted for: Lewis Cass, Jr.'s “accidentally mislaid” March 1853 letter assuring papal authorities that Bedini would receive a respectful reception in the United States. ${ }^{237}$ As historian James Connelly noted, this rather "convenient mistake" excused Marcy from having to justify his long-standing

${ }^{233}$ National Era, January 25, 1854.

${ }^{234}$ Weekly Herald, January 28, 1854; New York Tribune quoted in the Milwaukee Daily Sentinel, January 31, 1854. See also Columbian Register (New Haven, Conn.), February 4, 1854; Milwaukee Daily Sentinel, February 3, 1854; National Era, January 25, 1854; January 28, 1854.

${ }^{235}$ New York Express quoted in the Daily Cleveland Herald, February 1, 1854.

${ }^{236}$ National Era, January 25, 1854; Milwaukee Daily Sentinel, February 7, 1854.

${ }^{237}$ Secretary of State William Marcy, Message to the United States Senate, January 25, 1854, quoted in Connelly, Visit of Archbishop Gaetano Bedini, 126. 
refusal to acknowledge the Nuncio's diplomatic status, just as it prevented senators from investigating whether the younger Cass had promised Bedini more support and security than federal officials provided. ${ }^{238}$ With his congressional duties nevertheless complete, the Secretary wrote directly to his chargé in Rome, blaming the disturbances on "a few individuals which have been discountenanced by the Government and generally reprobated by our citizens."239 While this letter, which was ultimately intended for Vatican officials, made no direct mention of Bedini's immigrant critics, Marcy's reference to protestors who had forgotten the virtues of republican hospitality during "moments of excitement" clearly indicted the nation's supposedly volatile foreign-born population. President Pierce, in contrast, had greeted the Nuncio in a respectful and dignified manner, just as most citizens disapproved of the émigrés" "annoyances" against the Nuncio. These protestors had embarrassed Bedini and abused America's hospitality, Marcy argued, but they had not damaged their host nation's friendly relations with Rome or its global reputation for freedom, justice, and republican virtue.

The Secretary's diplomatic overtures temporarily assuaged Vatican officials, but his couched language obscured the growing domestic backlash against Bedini. The elder Cass's efforts to exonerate the Nuncio backfired, as increasing numbers of nativists joined émigrés in describing Bedini as an unaccredited and unwelcomed autocrat. Southern editors cited the State Department's newly-released documents to argue that Bedini belonged in Brazil rather than the United States, while Philadelphia residents organized a mass meeting to denounce the Nuncio and his Senate supporters. ${ }^{240}$ Philadelphians especially lashed out against newspapers such as the Baltimore Sun, which described Bedini's mission as "respectful and conciliatory," by calling on

${ }^{238}$ Connelly, Visit of Archbishop Gaetano Bedini, 127.

${ }^{239}$ Secretary of State William Marcy, letter to Lewis Cass, Jr., January 30, 1854, quoted in Connelly, Visit of Archbishop Gaetano Bedini, 128.

${ }^{240}$ Connelly, Visit of Archbishop Gaetano Bedini, 128-130; Fayetteville Observer (North Carolina), February 2, 1854; Boston Daily Evening Transcript, February 13, 1854. 
federal authorities to suspend all diplomatic ties with Rome. ${ }^{241}$ Not to be outdone, New York City's Italian exile community organized a similar mass meeting and mock trial against the infamous counterrevolutionary. These demonstrators found Bedini guilty of spying on republican troops in 1849, colluding with Austrian authorities, and overseeing the execution of scores of freedom fighters, including Bassi, "the fourth great Patriot” of Italy's independence movement. "The time has come for us," their Address read, "to raise a fatal veil from you [Bedini] and make known to the World how sanguinary was your soul, how sacrilegious was your Catholic ministry." 242 Newspaper editors greeted these Gavazzi-inspired descriptions of Bolognese bloodletting with a mix of support and skepticism, but nativists enthusiastically cited them as further proof of both Bedini's conspiratorial past and Catholicism's depraved nature. ${ }^{243}$ Other native-born observers ignored the Bologna controversy altogether to concentrate on the Nuncio's violent American record: "wherever he [has] appeared," North Carolina's Fayetteville Observer concluded, "a riot followed." 244 Whether out of righteous anger or relief that the crisis had finally passed, most non-Catholic residents were happy to hear of the Nuncio's February 4, 1854 departure for Europe. ${ }^{245}$

Bedini's hasty exit spurred soul-searching among Catholic prelates, who criticized governmental officials and foreign exiles even as they praised American laymen and extolled sanctity. Louisville Bishop Martin Spalding complained that the Nuncio's accreditation to Brazil provided authorities with a ready-made excuse to ignore him, while St. Louis Archbishop Peter Kenrick observed that officials seemed "powerless before the prejudices of the public and the

\footnotetext{
${ }^{241}$ Baltimore Sun, January 28, 1854. See also the Trenton State Gazette (New Jersey), February 14, 1854.

${ }^{242}$ New York Italian Address quoted in the Daily Cleveland Herald, February 4, 1854. See also Connelly, Visit of Archbishop Gaetano Bedini, 135-138.

${ }^{243}$ Baltimore Sun, February 2, 1854; Richmond Whig quoted in the National Era, February 14, 1854; Ohio State Journal (Columbus), February 21, 1854.

${ }^{244}$ Fayetteville Observer, February 9, 1854.

${ }^{245}$ Daily Cleveland Herald, February 7, 1854; Vermont Journal, February 10, 1854; Baltimore Sun, February 6, 1854; Connelly, Visit of Archbishop Gaetano Bedini, 141-144.
} 
violence of the mob." ${ }^{246}$ Archbishop John Hughes agreed that American civic leaders, despite the Senate's urging, had failed to uphold the dictates of decency and hospitality. But Hughes ultimately held foreign enemies of the Church responsible for the protests: "the ill feeling towards you," he later wrote the Nuncio, was primarily "the result of a dark and diabolical conspiracy between renegade Italians and atheistical Germans."247 The outspoken Archbishop further assured Bedini that these radicals were hated by all true American citizens, who valued virtue and abhorred the foreigners' violent doctrines and mobocratic tendencies. Bedini agreed, describing his enemies as wayward exiles "who are as bitter enemies of their own country as they are ingrates towards the country which lavishes upon them generous hospitality."248 The Nuncio claimed that he would always cherish his American experiences and remain grateful for the kind treatment he received from countless Catholic and Protestant citizens. American officials, on the other hand, were far less welcoming: one must "distinguish between the nation and the government," the Nuncio concluded, for while "the first ... [was] amiable to me, the other has been entirely indifferent and, God grant that I am wrong, hostile."249 Bedini's piety was even more pronounced in his widely-published February 17 letter to Baltimore Archbishop Francis Kenrick, which mixed criticism of national leaders with scriptural references and prayers for Gavazzi's repentance. How ironic, the Nuncio noted, that the same demonstrators who

\footnotetext{
${ }^{246}$ Archbishop Peter Kenrick, letter to Archbishop John Purcell, February 9, 1854, Archdiocesan Records, Electronic Archival Calendar, University of Notre Dame Archives (Notre Dame, Ind.); Bishop Martin Spalding, letter to Archbishop John Purcell, February 14, 1854, Archdiocesan Records, Electronic Archival Calendar, University of Notre Dame Archives (Notre Dame, Ind.). See also Connelly, Visit of Archbishop Gaetano Bedini, $160-161$

${ }^{247}$ Archbishop John Hughes, letter to Archbishop Gaetano Bedini, July 2, 1854, Archbishop John Hughes Papers, American Catholic History Research Center and University Archives, Catholic University of America (Washington, DC). See also Connelly, Visit of Archbishop Gaetano Bedini, 151-156; Archbishop John Hughes, letter to Archbishop Anthony Blanc, February 3, 1854, Archbishop John Hughes Papers, American Catholic History Research Center and University Archives, Catholic University of America (Washington, DC).

${ }^{248}$ Archbishop Gaetano Bedini, letter to Archbishop John Hughes, February 3, 1854, Archbishop John Hughes Papers, American Catholic History Research Center and University Archives, Catholic University of America (Washington, DC). ${ }^{249}$ Ibid.
} 
believed the tales of a single apostate priest still refused to trust the thousands of individuals who attested to Marian apparitions. Bedini also presented Kenrick and his brother bishops with engravings of an Italian portrait of Our Lady of Rimini, praying that Mary would "turn her merciful eyes upon your land ... [and] work the not less rare miracle of opening their [his opponents] eyes to ideas more true, most just, dear and holy." ${ }^{250}$ In spite of the hatred and lies he had encountered in the United States, Bedini - like Christ - promised to love his enemies and pray for his persecutors.

National newspaper editors scoffed at Bedini's letter, describing it as a sanctimonious example of Catholic superstition. The Nuncio's critics especially focused on his references to the portrait in Rimini's Santa Chiara Church, which Catholics claimed had inexplicably moved its eyes several times during Bedini's tenure in nearby Bologna. ${ }^{251}$ "Of course, then, all must be right," Bedini's erstwhile supporters at the National Era noted, for "what if Ugo Bassi was skinned alive! What if scores of other patriots were smothered in dungeons, or handed over to the Austrians to be shot? The miracle sanctifies all this."252 Even the Nuncio knew that the painting was a fraud, the editors continued, but by dwelling on this "miracle" he hoped to distract Americans from his heinous crimes. ${ }^{253}$ The Boston Courier similarly mocked the "tone of feigned humility" in Bedini's "silly letter," accusing him of insulting the wisdom and good sense of all democratic citizens. ${ }^{254}$ Others contrasted Catholic Italy's ready acceptance of the supernatural and its acquiescence to papal tyranny with Protestant America's exceptional and discerning views on religion and politics. As one poetic critic wrote, "Bedini prefers his own

\footnotetext{
${ }^{250}$ Archbishop Gaetano Bedini, letter to Archbishop Francis Kenrick, February 17, 1854, quoted in Connelly, Visit of Archbishop Gaetano Bedini, 149.

${ }^{251}$ For a brief description of Our Lady of Rimini, see Connelly, Visit of Archbishop Gaetano Bedini, 140.

${ }^{252}$ National Era, quoted in the Boston Liberator, April 21, 1854. See also the Fayetteville Observer, April 10, 1854; National Era, April 4, 1854.

${ }^{253}$ National Era, April 7, 1854.

${ }^{254}$ Boston Courier, April 6, 1854.
} 
land to our own, Thinks another short visit to us would be shrinked at, The cause - his monstrosities here are frowned down, While at home we've his modest assurance they're winked at. ${ }^{, 255}$ Earlier debates over Gavazzi’s veracity, American citizenship, Bedini’s diplomatic status, and the limits of democratic dissent all faded as editors presented the Nuncio's tour as a cautionary tale on the temporal and spiritual excesses of Roman Catholicism. "A few more Bedinis, and winking Madonnas of Rimini," the New York Observer noted, "and Popery will be the synonym of absurdity."256

While nativists employed sensationalist storylines to describe Bedini as an enemy of humanity, American bishops continued to view the Nuncio's visit as the Gethsemane of their generation. Know Nothing propagandists quickly adopted Gavazzi’s Italian tales of republican purity and corruption, but subtly adapted the accounts to reflect domestic anti-Catholic fears and stereotypes. Following in the veritable tradition of Maria Monk's Awful Disclosures and other famed convent exposés, anti-Bedini rhetoricians provided especially violent descriptions of the Nuncio’s crimes against female virtue. In Bedini's Bologna, “the naked bodies of the noble woman [sic] of Italy were placed upon the block and wipped [sic] by the rough hands of the hangman," one broadside claimed, "until the blood was flowing! - until the bones became barren of flesh!" ${ }^{257}$ Bedini similarly became the star of several papal conspiracy tales, with various authors accusing him of instituting an American Inquisition, creating secret societies and assassination squads, exhorting bishops to abuse Protestants, bribing public officials and citizens, and manipulating electoral returns. ${ }^{258}$ Nativists also successfully re-imagined the "Bedini Affair" as a proper American uprising against Catholic provocations rather than as an effort to avenge

${ }^{255}$ National Era, April 25, 1854. Emphasis original.

${ }^{256}$ New York Observer quoted in the Ohio Observer (Hudson, OH), May 24, 1854.

257 "The Pope's Nuncio. Bedini's character." American Broadsides and Ephemera, Series I, unknown publication date and location; Frink, "American Anti-Catholic Narratives," 237-263.

${ }^{258}$ Endres, "Reassessing the Visit," 14-15. 
republican losses in Europe. Revisionist accounts emphasized the decisive role of Know Nothing protestors at the expense of foreign-born activists, who were now cast in supporting roles. "If it was a German mob who burned him [Bedini] in effigy at Cincinnati - if it was an Italian junta that promised to do the same thing in New Orleans," the New York Express argued, "it was AMERICANS who turned out, some three thousand strong, to bid him a glad farewell."259 National editors described Gavazzi and Bedini as catalysts of the Know Nothings' rise, while British newspapers - which had earlier linked the Bedini protests to lingering memories of 1848 - now focused on nativist opposition to the Nuncio. ${ }^{260}$ Yet Catholic leaders courted these condemnations, arguing that the notoriety would ultimately lead souls to the truth. "This bad feeling has unquestionably done us good," Archbishop Hughes noted, "so much, indeed, that our religion is under general investigation. All men are discussing it. No other creed seems worthy of the slightest notice."261 In Catholic hands, the "Bedini Affair" was reshaped to resemble a biblical lesson on patience and perseverance. So long as bishops and laymen stayed awake through the dark night of antebellum prejudice, they would come to witness the resurrection of American society.

These pious and political tales marked Bedini's transformation from a reminder of European rebellions to an American morality lesson. As the Nuncio emerged as a key figure in the anti-Catholic canon, bishops and laymen came to view him as a modern-day martyr whose kindness and humility in the face of persecution embodied the moral strength of Roman Catholicism. These selective memories highlighted the uncertain, and often hysterical, nature of

\footnotetext{
${ }^{259}$ New York Express quoted in the Daily Cleveland Herald, February 1, 1854. Emphasis original.

${ }^{260}$ London Daily News, February 6, 1854; Home and Foreign Record of the Free Church of Scotland, July 1, 1854; London News, January 14, 1854; London Gazette, January 14, 1854; The Farmers Cabinet (Amherst, NH), February 16, 1854; Weekly Herald, June 24, 1854; July 8, 1854.

${ }^{261}$ Archbishop John Hughes, letter to Cardinal Alessandro Barnabò, August 7, 1855, quoted in Guilday, "Gaetano Bedini," 169-170. See also Endres, "Reassessing the Visit," 16.
} 
antebellum sectarian conflicts even as they obscured the local partisan and ethnic divisions that fostered the Bedini crisis. Long before nativists took note of the Nuncio's arrival, political exiles were already relying on republican myths and revolutionary rhetoric to gain public sympathy for the cause of European liberty at Bedini's expense. These efforts were largely unsuccessful until police brutality and popular fears of mobocracy caused native-born residents to reflect on the meanings of democracy, free speech, and religious liberty. The Nuncio's ambiguous temporal status engendered conflict and controversy, as exiles and nativists voiced familiar fears of "Popery" while Catholics complained that the fallen world still refused to see the Light. Bedini's departure alleviated many of these immediate temporal concerns, which were redirected by Bleeding Kansas and other conflicts, but memories of his visit would continue to haunt Protestants, and encourage Catholics, for years to come. By condensing this conflict-ridden, complicated, and contradictory event into a unified narrative, contemporaries and later historians replaced concurrent crises with one simplified "Affair."

The first Bedini conflict centered on the social aspirations and political frustrations of European émigrés, whose efforts to scapegoat the Nuncio intersected with exceptionalist ideology and political conservatism. European exiles, inspired by Gavazzi’s nationalist rants and sensationalist sagas, became Bedini's first and fiercest foes in the United States. By building upon established Atlantic anti-Catholic narratives, these activists hoped to cast the Church as a temporal tyrant even as they exonerated republican leaders from blame for the 1848 defeats. $^{262}$ Early anti-Bedini rhetoric, in fact, portrayed opposition to the Nuncio as a liberal and cosmopolitan continuation of the 1848 uprisings: references to Bologna and Pope Pius IX abounded, while activists justified their actions by referencing global values and universal ideals.

\footnotetext{
${ }^{262}$ Manuel Borutta, "Anti-Catholicism and the Culture War in Risorgimento Italy," in The Risorgimento Revisited, eds. Patriarca and Riall, 191-193; Billington, Protestant Crusade, 300; Levine, Spirit of 1848, 47-48; Endres, "Reassessing the Visit," 7.
} 
These radical references disturbed many native-born residents, who feared any allusion to socialist violence and social upheaval. Radical émigrés, citizens charged, were using Bedini's visit as a pretext to reshape the United States into a violent, mob-ridden agnostic state. Newspapers denounced these trespasses against civility and constitutionalism in New Orleans, just as Cincinnati policemen took to the streets to protect the Sabbath. Exiles struck back in New York and elsewhere, producing ever-growing lists of the Nuncio's alleged victims and strongly deploring his offenses against humanity. Even so, this foreign Affair's focus on Continental events - as well as its flirtations with assassination plots and radical strands of European political thought - ensured that America's insular native-born population remained aloof, if not downright opposed, to early outbreaks of anti-Bedinism.

Cincinnati's Christmas violence shifted attention from international to domestic concerns, forcing politicians and voters to confront the limits of police authority and democratic dissent. In true exceptionalist style, only immigrants who established their credentials as both "American" liberals and respectable freemen - such as the Cincinnati Germans - were included in these localized debates, just as references to 1848 were replaced with sectional comparisons to federalism and "Slave Power" tyranny. For Whigs and nativists, the "Bedini Affair" ultimately appeared as an innocuous, if not commendable, exercise in civil liberty. Partisan and religious affiliations shaped the ongoing conflict, as Catholic and Democratic elites demanded responsible limits on free speech while critics compared these efforts to papal censorship and warned of the Church's continuing thirst for worldly authority. The uncertain divide between church and state frustrated both Protestants and Catholics, foiling efforts to provide Bedini with official diplomatic immunity and leading to Secretary of State Marcy's belated attempts to shore up relations with Rome. Outside of the diplomatic realm, the Nuncio's past history and current 
plight were overshadowed by the divisive democratic forces his visit unleashed. Native Cincinnatians denounced Bedini but mainly directed their anger towards civic officials such as Mayor Snelbaker and Police Chief Lukens, while most senators ignored the particulars of the Cincinnati disturbance to wax poetic on mobocracy, sectionalism, and free speech. These discussions and protests showcased many of antebellum America's unresolved dilemmas, but left the nation no closer to finding lasting solutions to these political and cultural crises.

Although legislative attention soon shifted to the Kansas-Nebraska conflict, Know Nothing propagandists ensured that the Nuncio's departure from New York marked his arrival as a conspiratorial cultural icon. Ironically, early nativist tales returned to the first Bedini Affair's descriptions of Bolognese brutality and often cited foreign tales as proof of the Nuncio's guilt. But Know Nothings viewed émigrés as corroborators rather than collaborators: while foreign anti-Bedini tales spoke of past republican betrayals in Europe, American anti-Bedini literature reflected fears of future moral and civic decline. This third "Affair" revolved around competing memories of the Nuncio's travels, with American bishops and laymen portraying his ecclesiastical tour as a success even as nativists publicly tied his visit to standard anti-Catholic stereotypes. In Catholic eyes, Bedini's harrowing tour strengthened ultramontanism and ultimately provided the American Church with needed spiritual purification and publicity. To nativists, the Nuncio's tour epitomized Catholicism's foreign character and illiberal nature. Only forceful republican resistance to papal politics, they claimed, would protect America's exceptional status and prevent the nation from devolving into another Italy. Bedini the man remained an enigma, but Bedini the symbol exemplified the democratic dreams and transatlantic tales that affected antebellum society and politics. 


\section{Bibliography}

\section{Primary Sources}

Government Records:

Congressional Globe, $33^{\text {rd }}$ Congress, $1^{\text {st }}$ Session 223-227 (1854).

Manuscripts

American Catholic History Research Center and University Archives, Catholic University of America, Washington, DC

Guilday, Peter. Lectures and Research Notes, 1884-1947.

Hughes, Archbishop John. Papers, 1853-1854.

Library of Congress, Washington, DC

Pierce, Franklin. Papers and Speeches, 1853-1854.

University of Notre Dame Archives, Notre Dame, Ind.

Archdiocesan Records, Electronic Archival Calendar. Official Records and Papers of the Catholic Prelates of Baltimore, Cincinnati, New Orleans, New York, and St. Louis, 18461854.

Brownson, Orestes. Papers, Electronic Archival Calendar, 1848-1854.

William L. Clements Library, University of Michigan, Ann Arbor, Mich.

Dickson, William. Papers, 1849-1912. Biographical Introduction.

$\underline{\text { Pamphlets and Handbills }}$

Gavazzi, Alessandro. The Lectures Complete of Father Gavazzi. New York: M.W. Dodd, 1854.

“The Pope's Nuncio. Bedini’s character.” American Broadsides and Ephemera, Series I.

Unknown publication date and location.

$\underline{\text { Periodicals }}$

Albany Evening Journal

Arkansas Whig (Little Rock)

Baltimore Sun

Boston Courier

Boston Daily Evening Transcript

Boston Liberator

Cayuga Chief (Auburn, NY)
Cincinnati Daily Enquirer

Columbian Register (New Haven, Conn.)

Daily Cincinnati Gazette

Daily Cleveland Herald

Daily Ohio Statesman (Columbus)

Farmers Cabinet (Amherst, NH)

Fayetteville Observer (North Carolina) 
London Examiner (England)

London Gazette (England)

London Journal (England)

London News (England)

Milwaukee Daily Sentinel

Mississippi Free Trader (Natchez)

Morning Chronicle and Commercial and

Shipping (Quebec City)

National Era (Washington, D.C.)

New Orleans Daily Picayune

Ohio Observer (Hudson, Ohio)

Ohio State Journal (Columbus)

Perrysburg Journal (Ohio)

Philadelphia North American
Philadelphia Public Ledger

Quebec Mercury (Quebec City)

Richmond Enquirer (Virginia)

Ripley Bee (Ohio)

Sharpe's London Journal (England)

The Constitution (Middletown, Conn.)

The Home and Foreign Record of the Free

Church of Scotland (Edinburgh)

The Leader and Saturday Analyst (England)

The Rambler (England)

Trenton State Gazette (New Jersey)

Vermont Journal (Windsor)

Weekly Herald (New York)

\section{$\underline{\text { Secondary Sources }}$}

Articles, Book Chapters, Dissertations, and Theses

Claeys, Gregory. "Mazzini, Kossuth, and British Radicalism, 1848-1854.” Journal of British Studies 28 (1989): 225-261.

Cohen, Daniel. "Passing the Torch: Boston Firemen, "Tea Party" Patriots, and the Burning of the Charlestown Convent." Journal of the Early Republic 24 (2004): 527-586.

Dolan, Timothy. “'Hence We Cheerfully Sent One Who Should Represent Our Person': A Century of Papal Representation in the United States." U.S. Catholic Historian 12 (1994): 1-26.

Drury, Marjule. "Anti-Catholicism in Germany, Britain, and the United States: A Review and Critique of Recent Scholarship." Church History 70 (2001): 98-131.

Endres, David. "Know-Nothings, Nationhood, and the Nuncio: Reassessing the Visit of Archbishop Bedini." U.S. Catholic Historian 21 (2003): 1-16.

Fenton, Elizabeth. "Birth of a Protestant Nation: Catholic Canadians, Religious Pluralism, and National Unity in the Early U.S. Republic." Early American Literature 41 (2006): 29-57.

Finn, Margot. “'A Vent Which Has Conveyed Our Principles': English Radical Patriotism in the Aftermath of 1848." The Journal of Modern History 64 (1992): 637-659.

Folk, Patrick. "“The Queen City of Mobs': Riots and Community Reactions in Cincinnati, 1788 -1848." Ph.D. dissertation, University of Toledo, 1978.

Frink, Sandra. "Women, the Family, and the Fate of the Nation in American Anti-Catholic Narratives, 1830-1860." Journal of the History of Sexuality 18 (2009): 237-264.

Furstenberg, Francois. "Beyond Freedom and Slavery: Autonomy, Virtue, and Resistance in Early American Political Discourse.” The Journal of American History 89 (2003): 12951330. 
Gerber, David. "Modernity in the Service of Tradition: Catholic Lay Trustees at Buffalo's St. Louis Church and the Transformation of European Communal Traditions, 1829-1855." Journal of Social History 15 (1982): 655-684.

Guilday, Peter. "Gaetano Bedini: An Episode in the Life of Archbishop John Hughes." Historical Records and Studies 23 (1933): 87-170.

Horner, Dan. "'Shame upon you as men!': Contesting Authority in the Aftermath of Montreal's Gavazzi Riot." Social History 44 (2011): 29-52.

Kenny, Stephen. "A Prejudice that Rarely Utters its Name: An Historiographical and Historical Reflection upon North American Anti-Catholicism." American Review of Canadian Studies 32 (2002): 639-672.

Le Beau, Bryan. "Saving the West from the Pope': Anti-Catholic Propaganda and the Settlement of the Mississippi River Valley." American Studies 32 (1991): 101-114.

Mairose, Mary Alice. "Nativism on the Ohio." M.A. thesis, The Ohio State University, 1993.

Marraro, Howard. "Italians in New York in the Eighteen Fifties Part II." New York History 30 (1949): 276-303.

. "The Religious Problem of the Italian Risorgimento as seen by Americans." Church History 25 (1956): 41-62.

McCann, Sister Mary Agnes. “The Most Reverend John Baptist Purcell, D.D., Archbishop of Cincinnati (1800-1883).” The Catholic Historical Review 6 (1920): 172-199.

Paludan, Phillip. "The American Civil War Considered as a Crisis in Law and Order." The American Historical Review 77 (1972): 1013-1034.

Paz, D.G. "Popular Anti-Catholicism in England, 1850-1851." Albion: A Quarterly Journal Concerned with British Studies 11 (1979): 331-359.

Radforth, Ian. "Political Demonstrations and Spectacles during the Rebellion Losses Controversy in Upper Canada." Canadian Historical Review 92 (2011): 1-41.

Ralls, Walter. "The Papal Aggression of 1850: A Study in Victorian Anti-Catholicism." Church History 43 (1974): 242-256.

Vecoli, Rudolph. "Priests and Peasants: Italian Immigrants and the Catholic Church." Journal of Social History 2 (1969): 217-268.

Verhoeven, Timothy. "Neither Male nor Female: Androgyny and International Anti -Catholicism." Australasian Journal of American Studies 24 (2005): 5-19.

Wolffe, John. "A Transatlantic Perspective: Protestantism and National Identitites in mid -Nineteenth-Century Britain and the United States." In Protestantism and National Identity: Britain and Ireland 1660-1850, edited by Tony Claydon and Ian McBride, 291309. Cambridge: Cambridge University Press, 1998.

. "North Atlantic Anti-Catholicism in the Nineteenth Century: A Comparative Overview." In European Anti-Catholicism in a Comparative and Transnational Perspective, edited by Yvonne Werner and Jonas Harvard, 25-41. Amsterdam: Rodopi, 2013. 
$\underline{\text { Books }}$

Altschuler, Glenn and Stuart Blumin. Rude Republic: Americans and Their Politics in the Nineteenth Century. Princeton: Princeton University Press, 2001.

Anbinder, Tyler. Nativism and Slavery: The Northern Know Nothings and the Politics of the 1850s. New York: Oxford University Press, 1992.

Billington, Ray Allen. The Protestant Crusade 1800-1860: A Study of the Origins of American Nativism. New York: The Macmillan Company, 1938.

Connelly, James. The Visit of Archbishop Gaetano Bedini to the United States of America: June 1853-February 1854. Rome: Pontifical Gregorian University, 1960.

Coppa, Frank. Pope Pius IX: Crusader in a Secular Age. Boston: Twayne Publishers, 1979.

D'Agostino, Peter. Rome in America: Transnational Catholic Ideology from the Risorgimento to Fascism. Chapel Hill: University of North Carolina Press, 2004.

Fenton, Elizabeth. Religious Liberties: Anti-Catholicism and Liberal Democracy in Nineteenth -Century U.S. Literature and Culture. New York: Oxford University Press, 2011.

Franchot, Jenny. Roads to Rome: The Antebellum Protestant Encounter with Catholicism. Berkeley: University of California Press, 1994.

Gemme, Paola. Domesticating Foreign Struggles: The Italian Risorgimento and Antebellum American Identity. Athens: University of Georgia Press, 2005.

Gilje, Paul. The Road to Mobocracy: Popular Disorder in New York City, 1763-1834. Chapel Hill: University of North Carolina Press, 1987.

Glazer, Walter. Cincinnati in 1840. Columbus: The Ohio State University Press, 1999.

Griffin, Susan. Anti-Catholicism and Nineteenth-Century Fiction. Cambridge: Cambridge University Press, 2004.

Grimsted, David. American Mobbing, 1828-1861: Toward Civil War. New York: Oxford University Press, 1998.

Hartnett, Stephen. Democratic Dissent and the Cultural Fictions of America. Urbana: University of Illinois Press, 2002.

Holt, Michael. The Political Crisis of the 1850s. New York: W.W. Norton, 1983.

Honeck, Mischa. We Are the Revolutionists: German-Speaking Immigrants \& American Abolitionists after 1848. Athens: University of Georgia Press, 2011.

Hughes, Steven. Crime, Disorder, and the Risorgimento: The Politics of Policing in Bologna. Cambridge: Cambridge University Press, 1994.

Isabella, Maurizio. Risorgimento in Exile: Italian Émigrés and the Liberal International in the Post-Napoleonic Era. New York: Oxford University Press, 2009.

Körner, Axel, editor, 1848- A European Revolution? International Ideas and National Memories of 1848. New York: St. Martin's Press, 2000.

Lamott, Rev. John H., S.T.D. History of the Archdiocese of Cincinnati, 1821-1921. Cincinnati: Frederick Pustet Company, 1921.

Levine, Bruce. The Spirit of 1848: German Immigrants, Labor Conflict, and the Coming of the Civil War. Urbana: University of Illinois Press, 1992. 
Light, Dale. Rome and the New Republic: Conflict and Community in Philadelphia Catholicism between the Revolution and the Civil War. Notre Dame, Ind.: University of Notre Dame Press, 1996.

McDaniel, W. Caleb. The Problem of Democracy in the Age of Slavery: Garrisonian Abolitionists and Transatlantic Reform. Baton Rouge: Louisiana State University Press, 2013.

McGreevy, John. Catholicism and American Freedom: A History. New York: W.W. Norton, 2003.

O'Connor, Thomas. Fitzpatrick's Boston, 1846-1866: John Bernard Fitzpatrick, Third Bishop of Boston. Boston: Northeastern University Press, 1984.

Patriarca, Silvana and Lucy Riall, editors, The Risorgimento Revisited: Nationalism and Culture in Nineteenth-Century Italy. New York: Palgrave Macmillan, 2012.

Pfau, Michael. The Political Style of Conspiracy: Chase, Sumner, and Lincoln. East Lansing: Michigan State University Press, 2005.

Roberts, Timothy. Distant Revolutions: 1848 and the Challenge to American Exceptionalism. Charlottesville: University of Virginia Press, 2009.

Rugemer, Edward. The Problem of Emancipation: The Caribbean Roots of the American Civil War. Baton Rouge: Louisiana State University Press, 2009.

Ryan, Mary. Civic Wars: Democracy and Public Life in the American City during the Nineteenth Century. Berkeley: University of California Press, 1997.

Senior, Elinor Kyte. British Regulars in Montreal: An Imperial Garrison, 1832-1854. Montreal: McGill-Queen's University Press, 1981.

Shaw, Richard. Dagger John: The Unquiet Life and Times of Archbishop John Hughes of New York. New York: Paulist Press, 1977.

Smith, Kimberly. The Dominion of Voice: Riot, Reason, and Romance in Antebellum Politics. Lawrence: University of Kansas Press, 1999.

Tocqueville, Alexis de. Democracy in America. Translated by Harvey Mansfield and Delba Winthrop. Chicago: University of Chicago Press, 2000.

Tuchinsky, Adam. Horace Greeley's 'New York Tribune': Civil War-Era Socialism and the Crisis of Free Labor. Ithaca, NY: Cornell University Press, 2009.

Verhoeven, Timothy. Transatlantic Anti-Catholicism: France and the United States in the Nineteenth Century. Basingstoke, England: Palgrave Macmillan, 2010. 